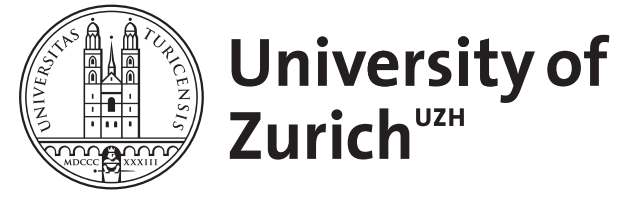

Zurich Open Repository and Archive

University of Zurich

University Library

Strickhofstrasse 39

CH-8057 Zurich

www.zora.uzh.ch

Year: 2014

\title{
From ironic distance to unexpected plot twists: unreliable narration in
} literature and film

Brütsch, Matthias

Posted at the Zurich Open Repository and Archive, University of Zurich

ZORA URL: https://doi.org/10.5167/uzh-101324

Book Section

Originally published at:

Brütsch, Matthias (2014). From ironic distance to unexpected plot twists: unreliable narration in literature and film. In: Alber, Jan; Krogh, Per. Beyond Classical Narration: Transmedial and Unnatural Challenges. Berlin: De Gruyter, 57-79. 
In: Albee, Jau/Hausen, Perkrogh (eds). Beyond (lassical Narration: Transmedial and Unnatural Challenges. Berlin: Waiter de Grunter, 2014.

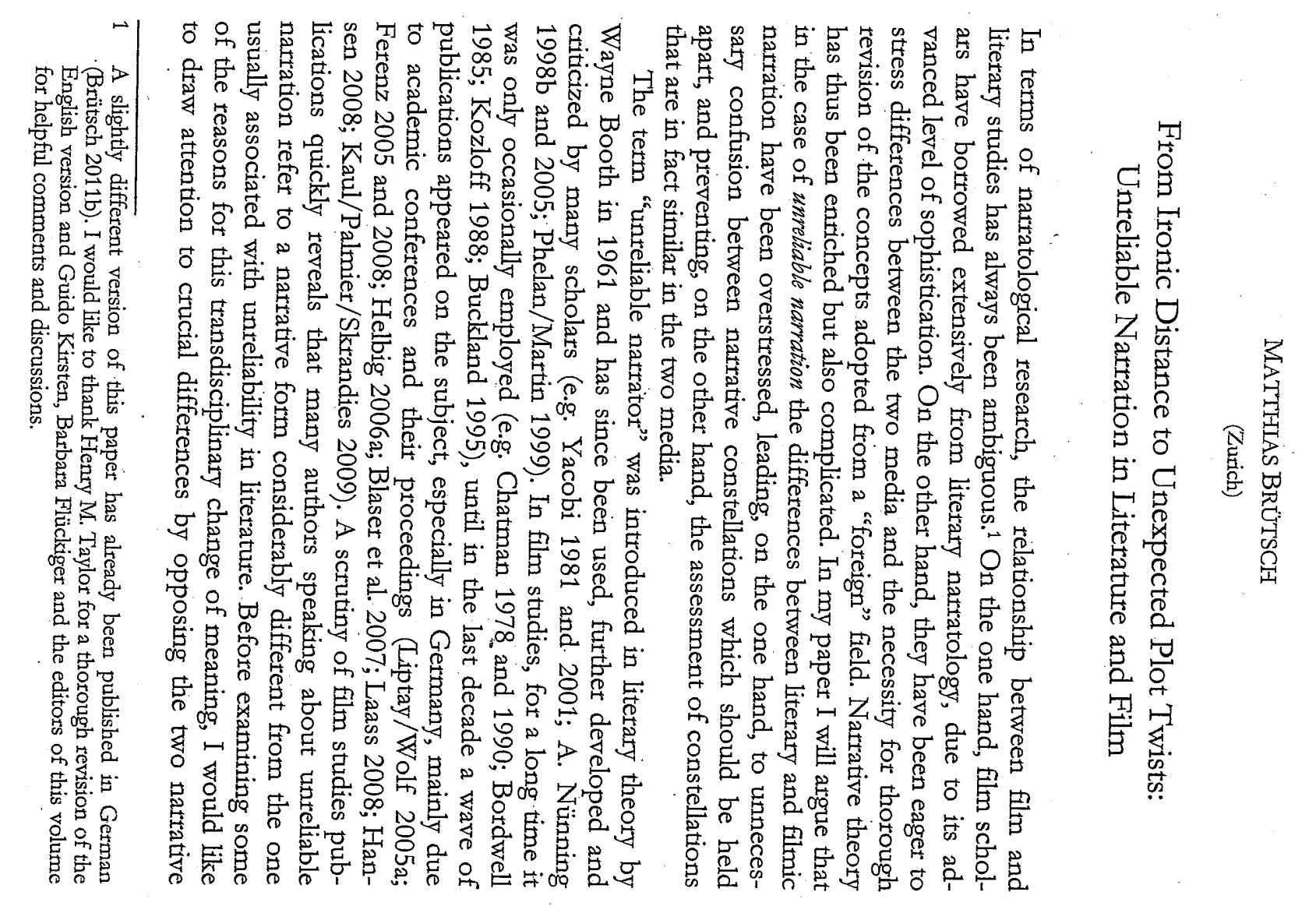




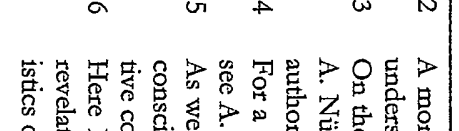

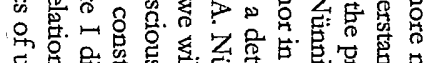

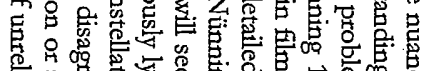

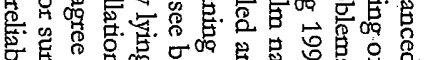

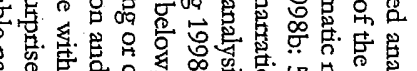

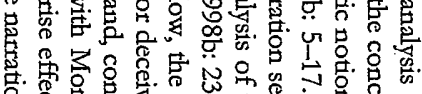

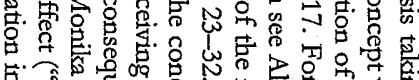

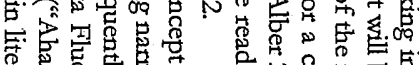

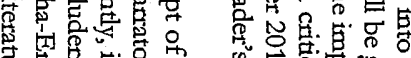

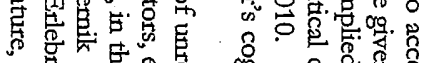
更 tos.

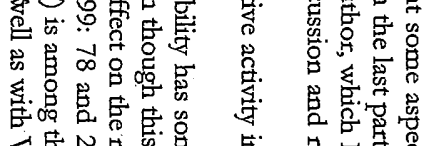

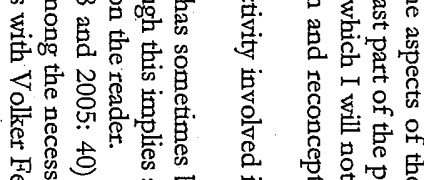

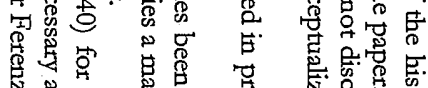

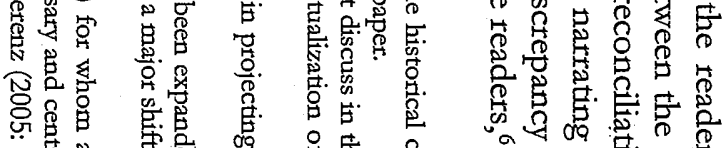

点营

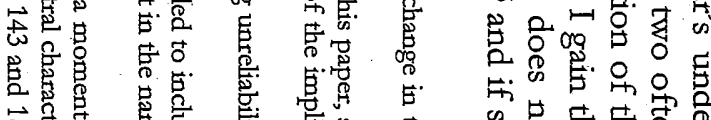

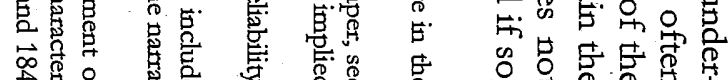

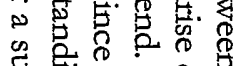

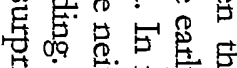
空

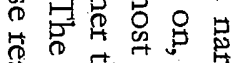

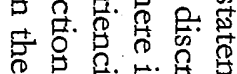

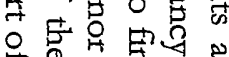

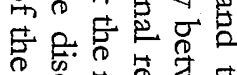

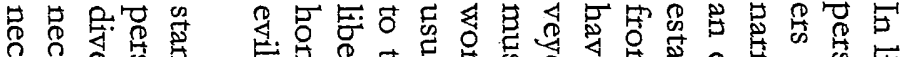

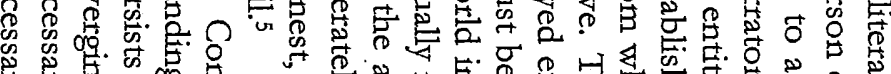

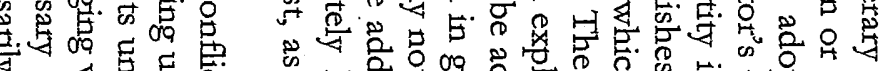

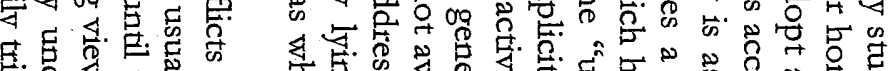

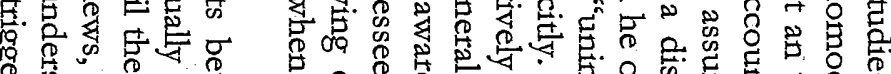

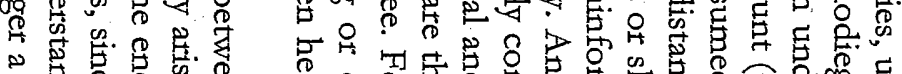

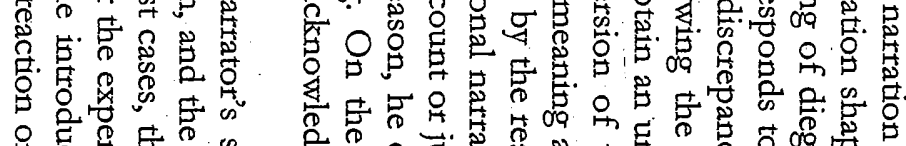

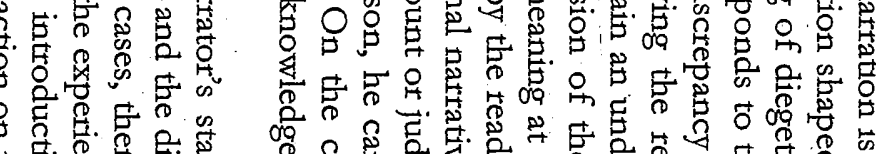

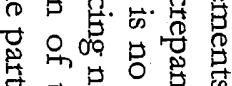

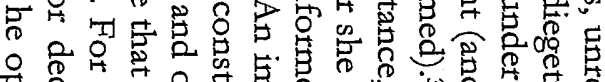

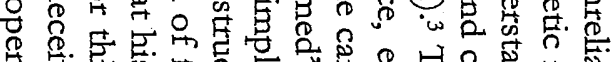

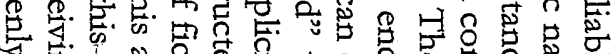

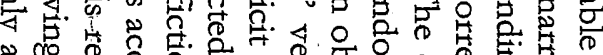

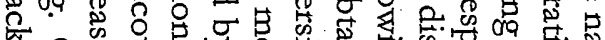

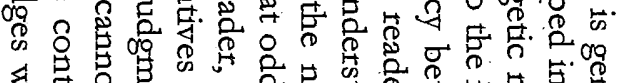

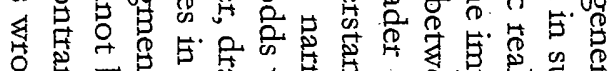

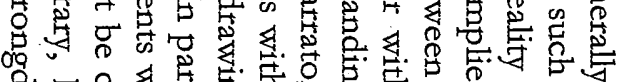

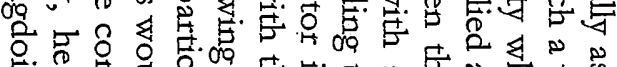

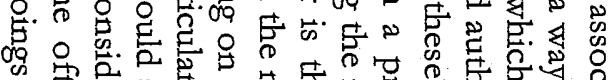

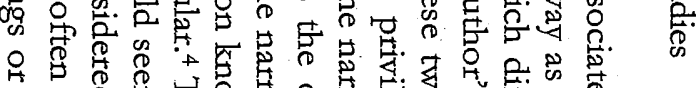

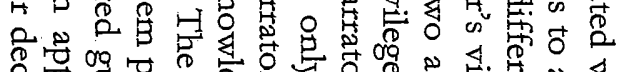

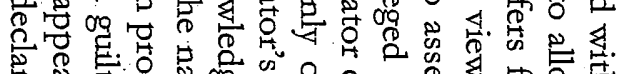

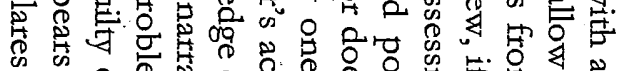

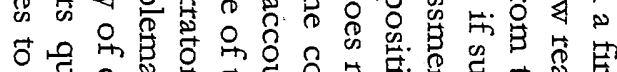

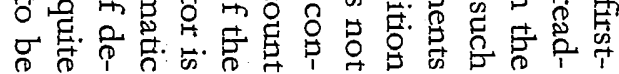

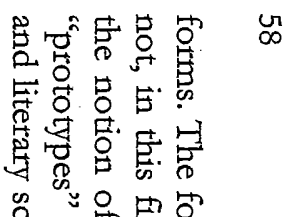

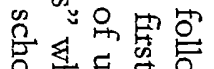

还居

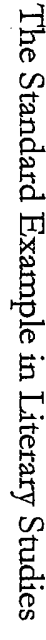

急要

芦品 8

尊昌是

可.

吕. 品 号.

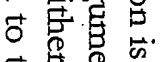

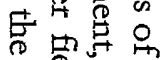

番总 8

要突葛

क के

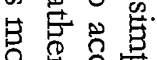

की

虽吕晋

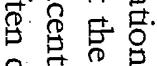

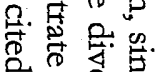

प्व 옴 量

导类品出

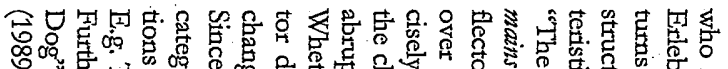

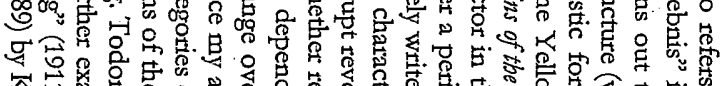

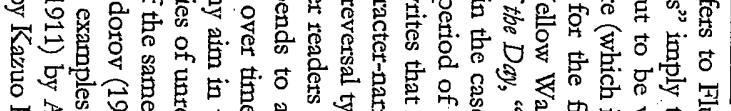

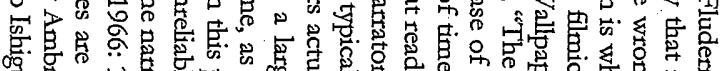

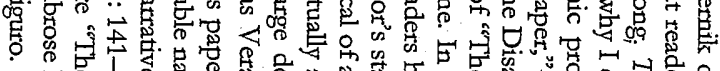

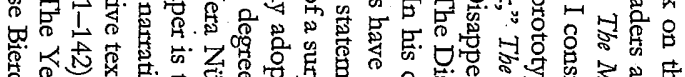

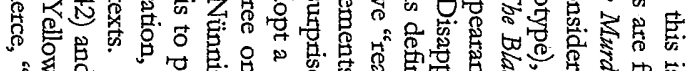

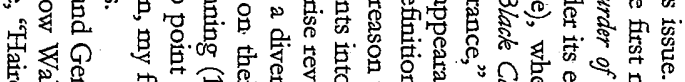

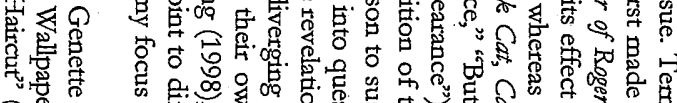

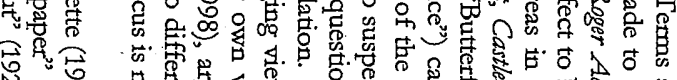

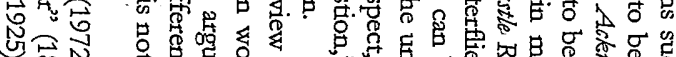

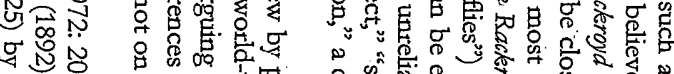

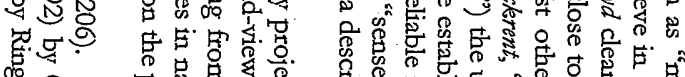

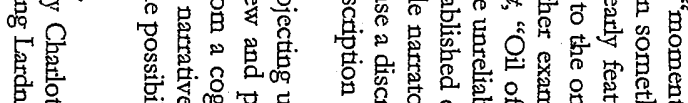

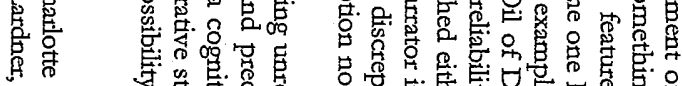

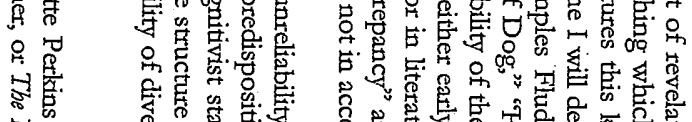

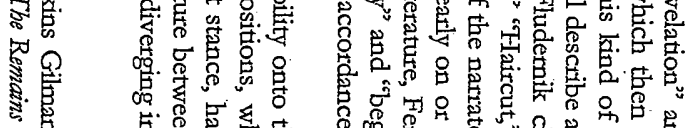

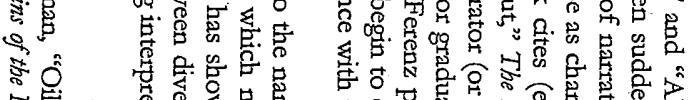

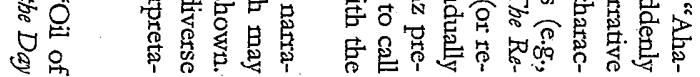

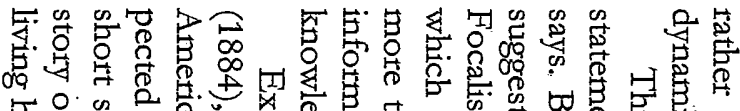

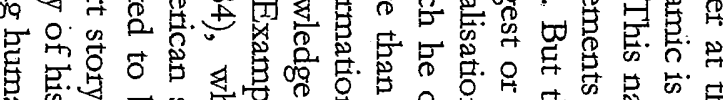

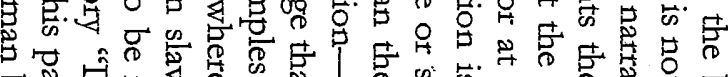

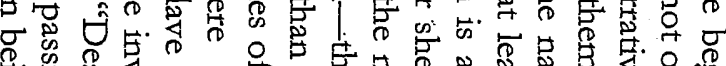

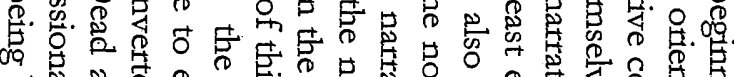

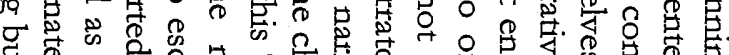

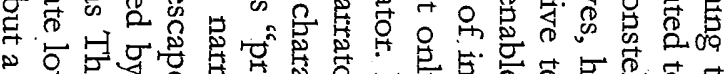

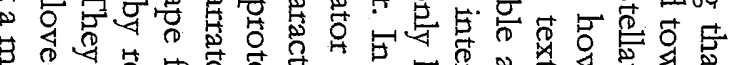

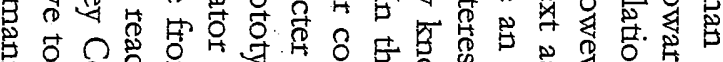

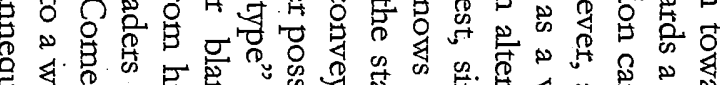

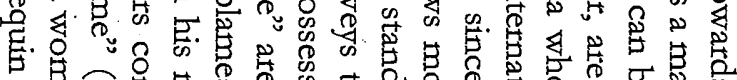

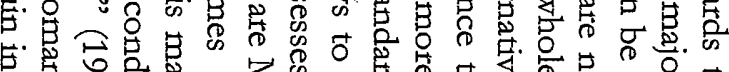

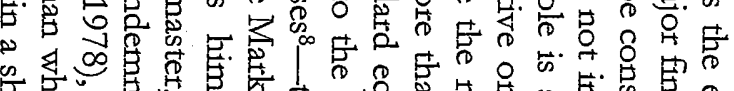

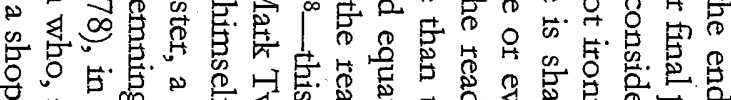

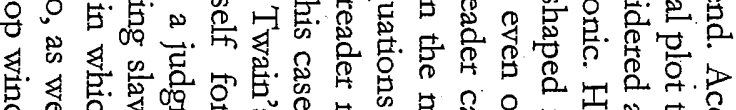
等

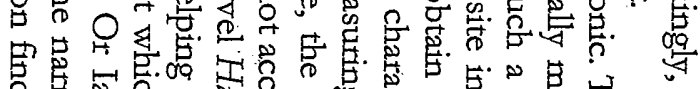

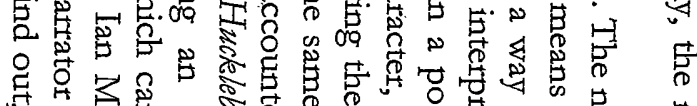

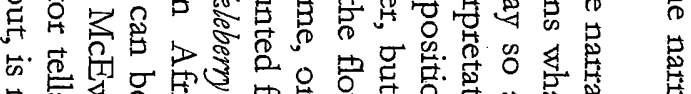

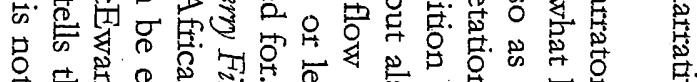

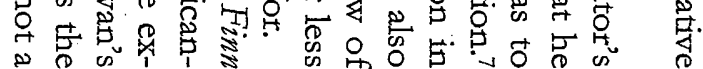


$\vec{\omega} \vec{N} \quad \overrightarrow{0}$

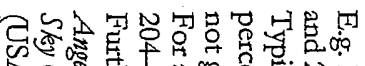

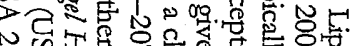

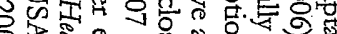

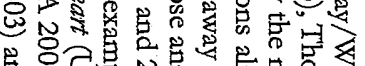

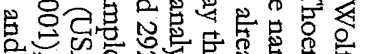

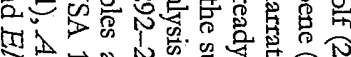

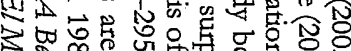

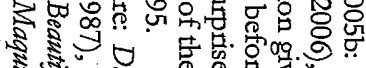
跣 5

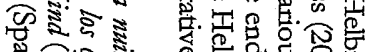

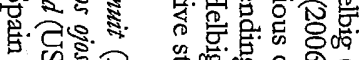

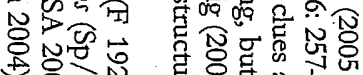

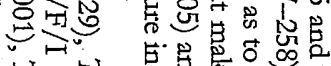

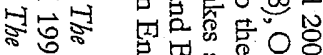

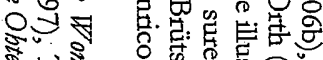

武爱

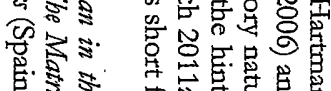

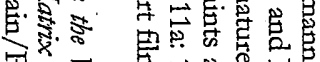

可要

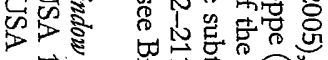

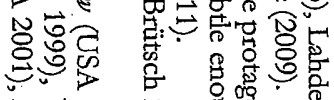

密密过

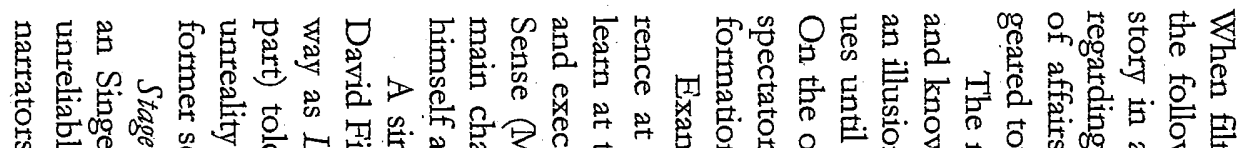
8

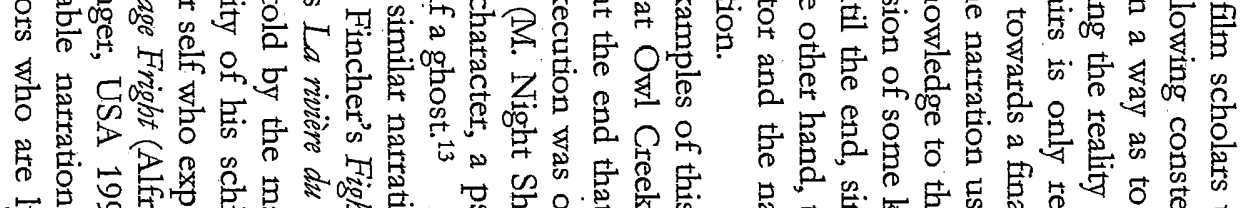

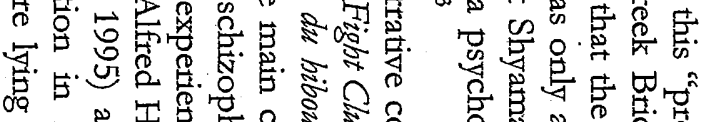

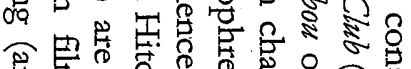

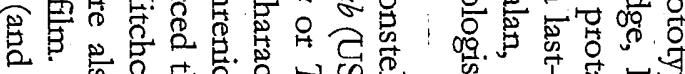

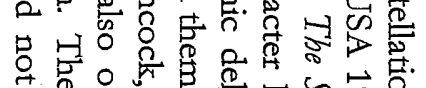

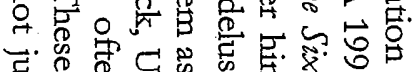

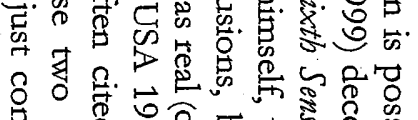

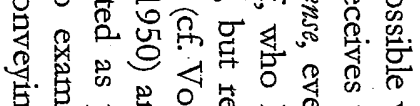

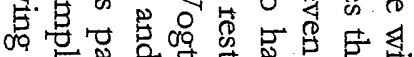

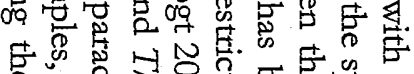

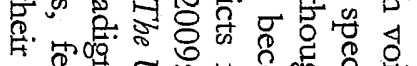

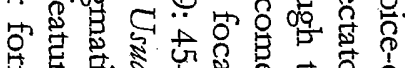

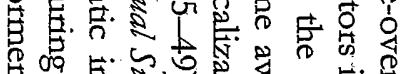

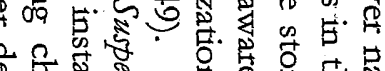

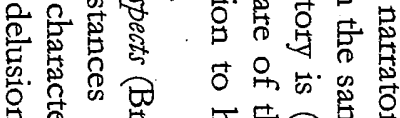

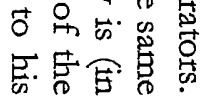

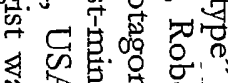

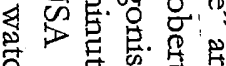

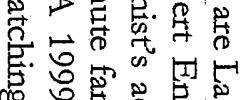
要

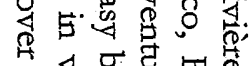

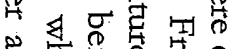
들: 可 5 .

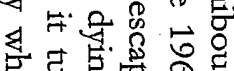

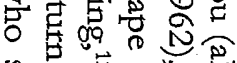

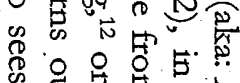
क

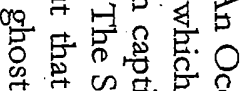
कs to

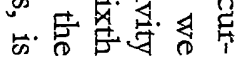

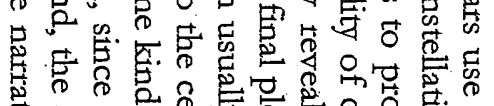

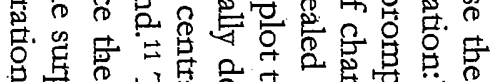
管.

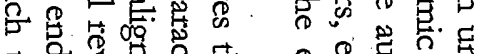

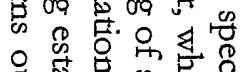
要品要

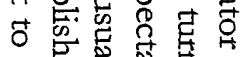

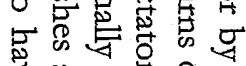

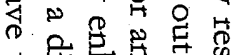

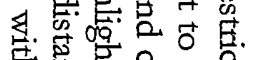

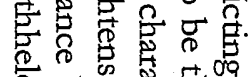

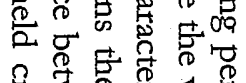

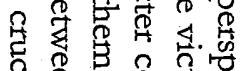

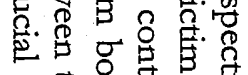

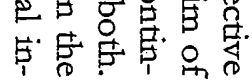

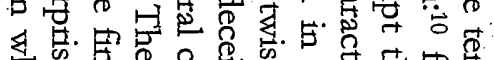

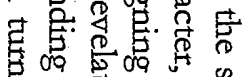

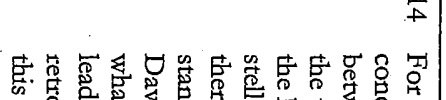

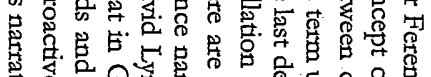

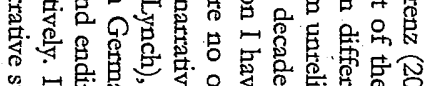

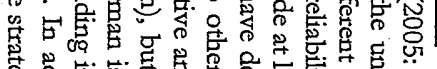

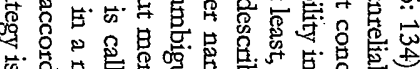

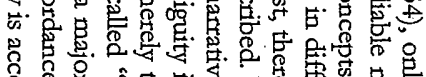
人

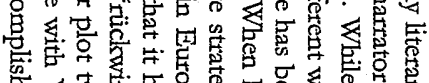
H

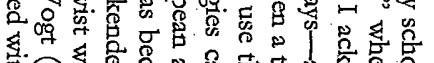
Be

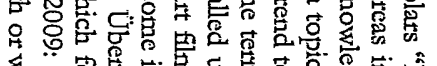

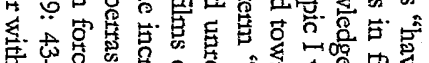

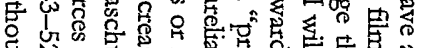

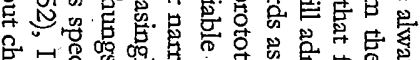

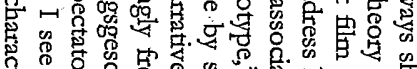
Ming The

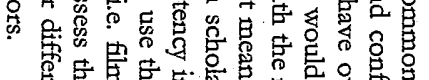

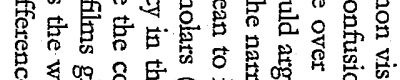
In:

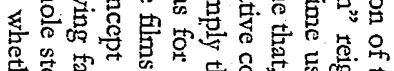

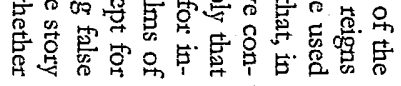

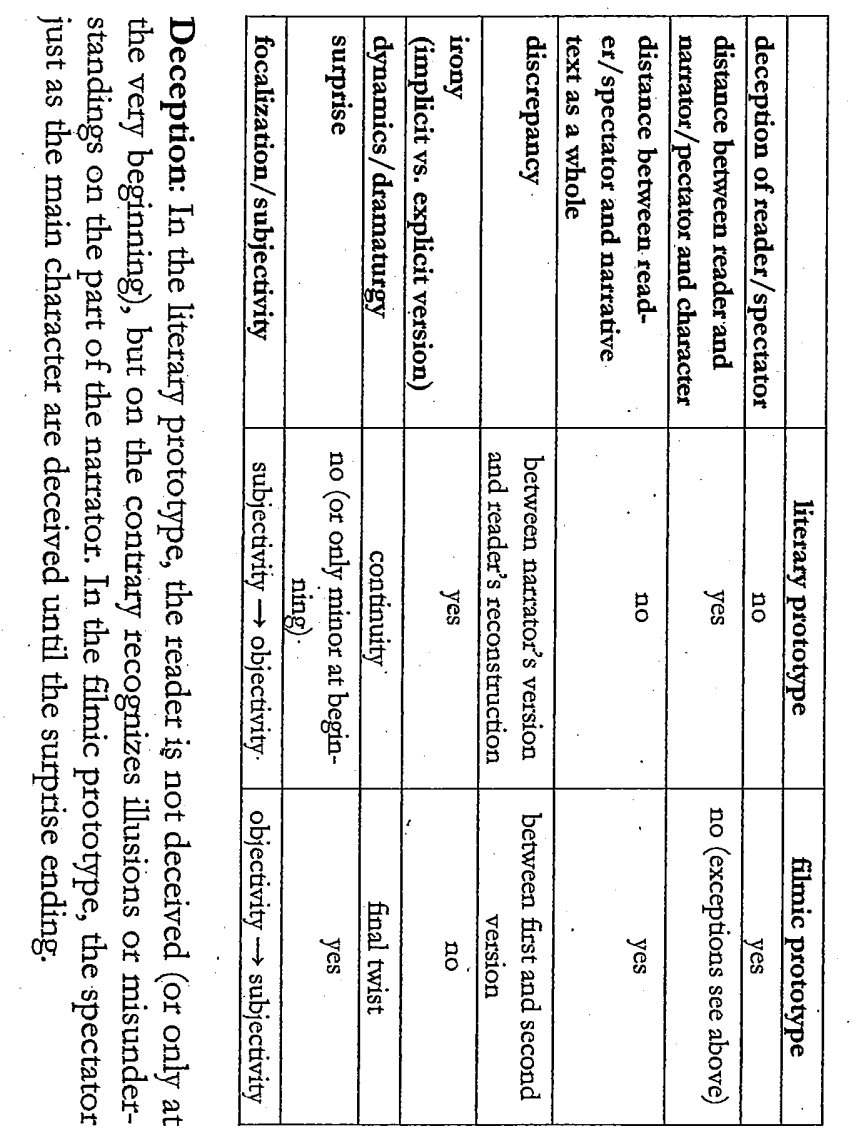

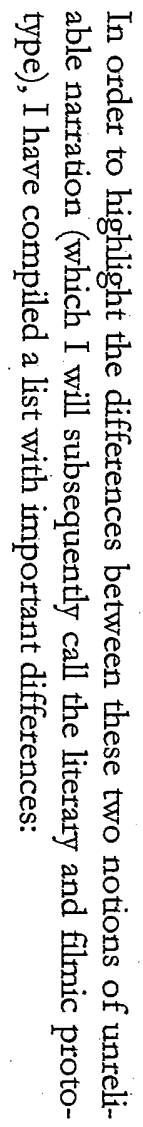

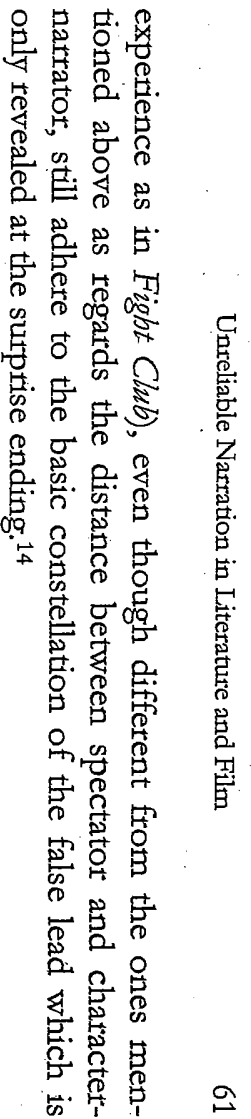




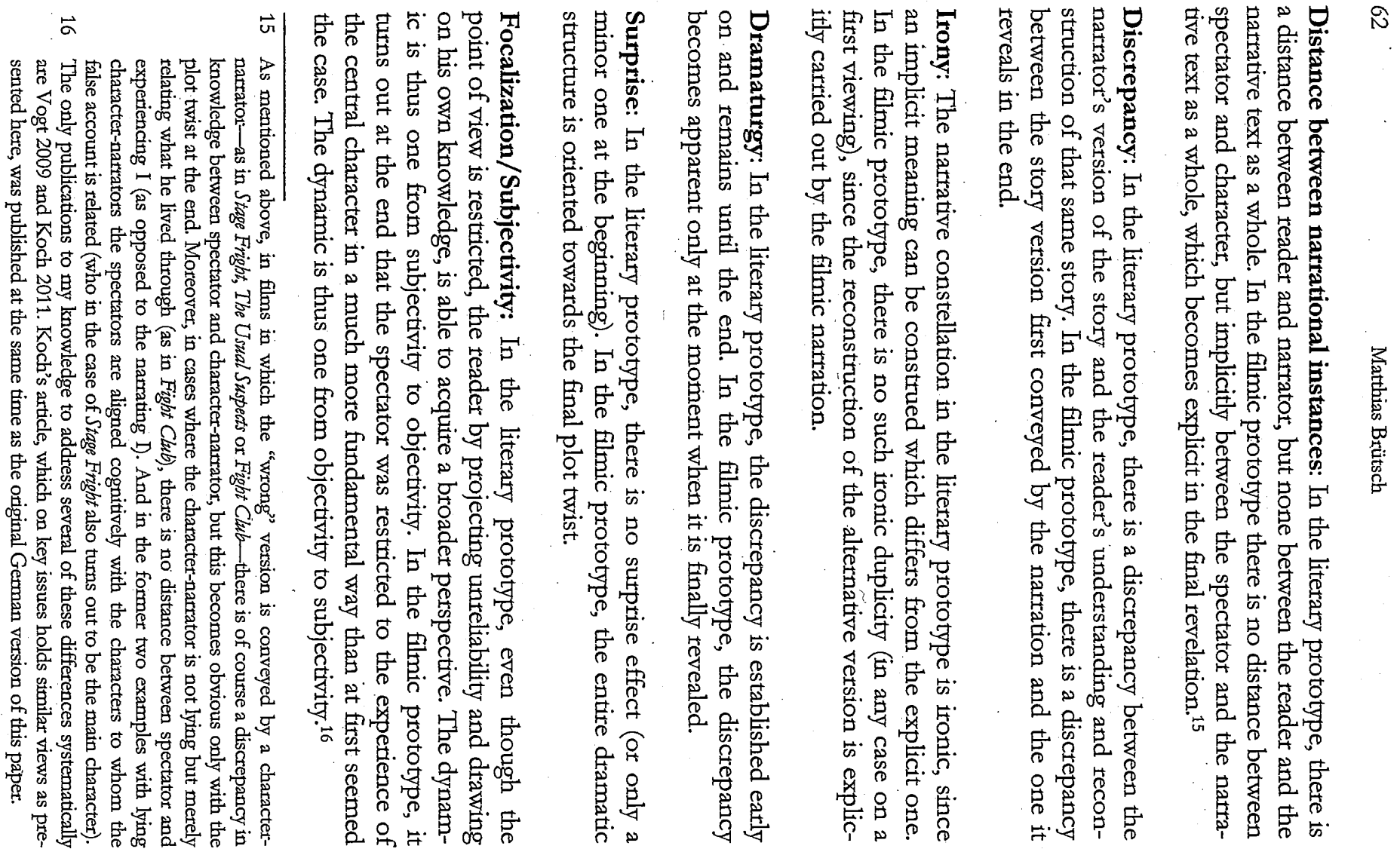

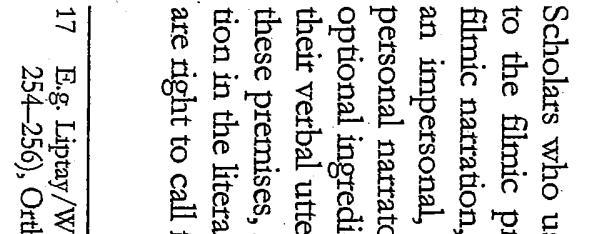

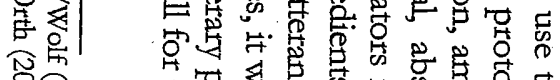

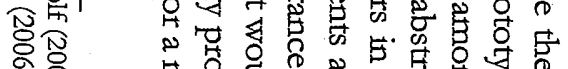

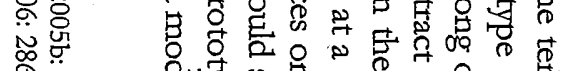

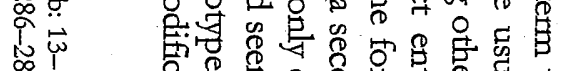

象

窟

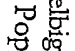

宫

可 :

훈

$\stackrel{\omega}{\oplus}$

突

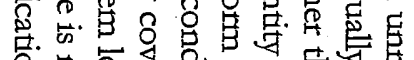

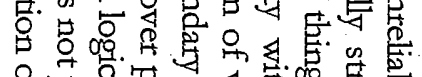

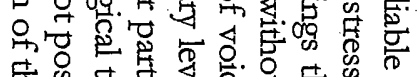

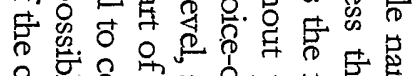

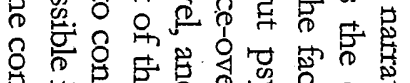

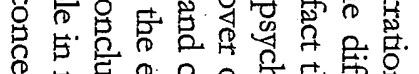

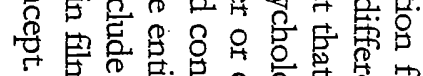

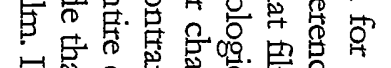

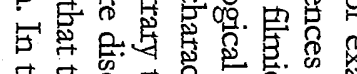

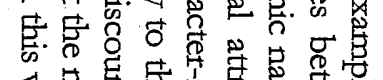

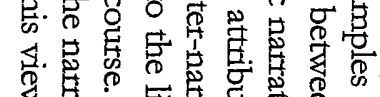

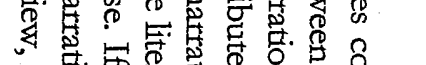

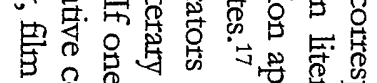

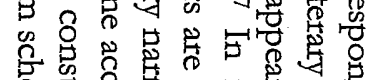

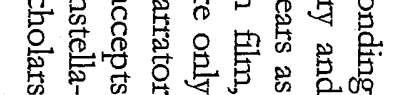

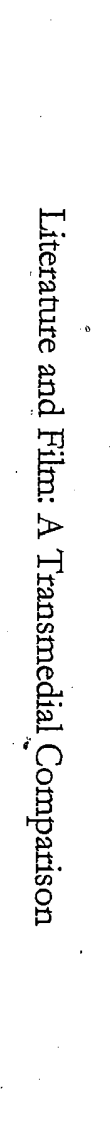

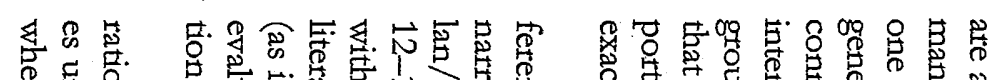

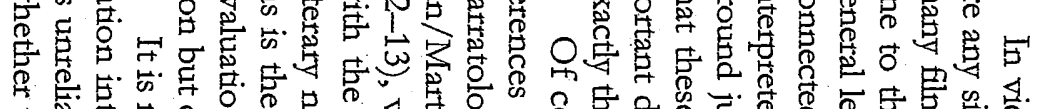

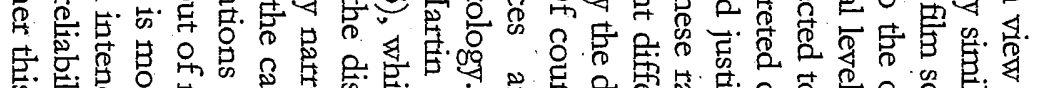

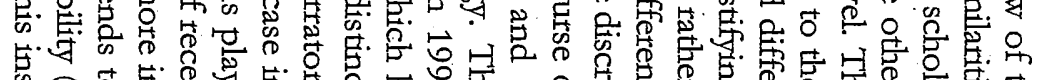

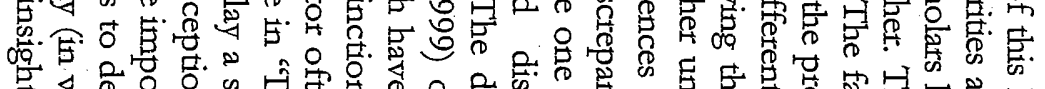

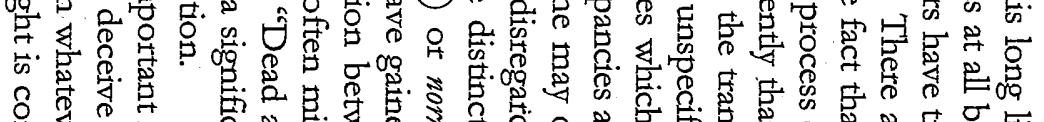

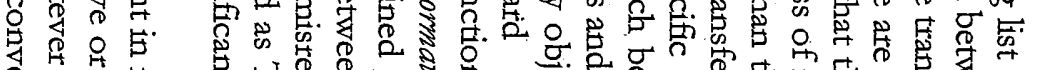

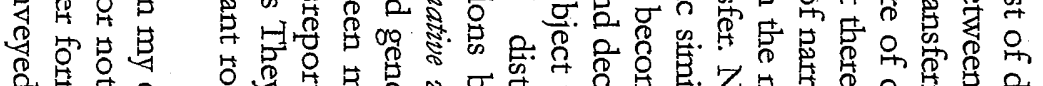

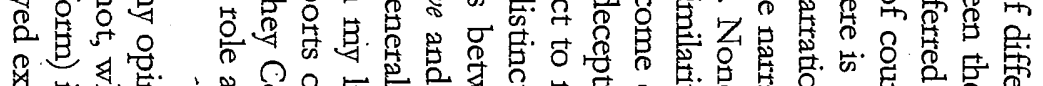

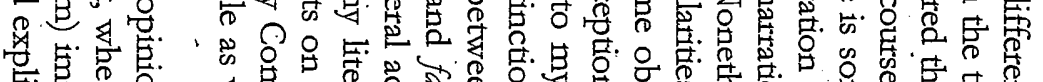

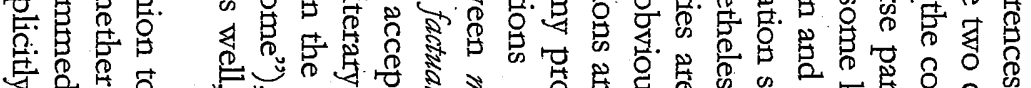

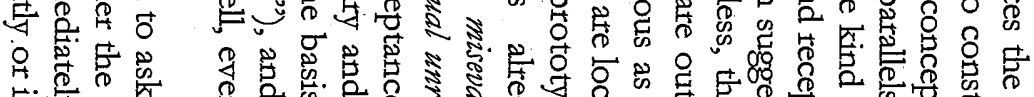

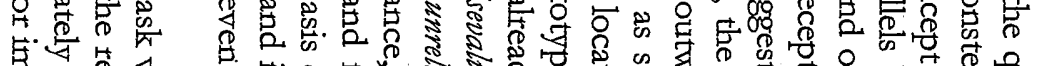

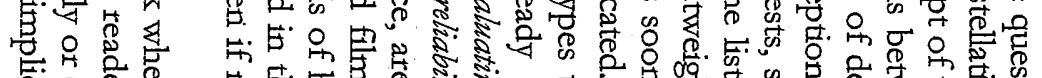

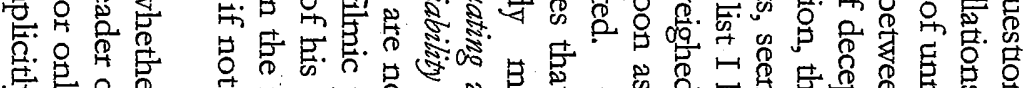

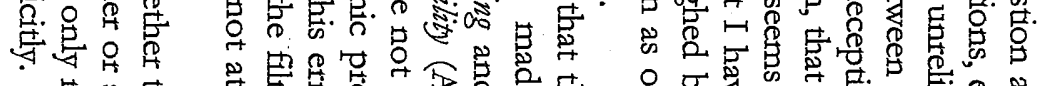

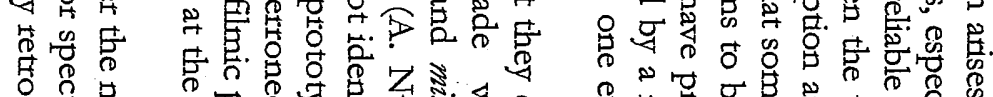

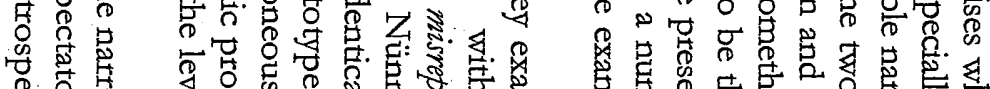

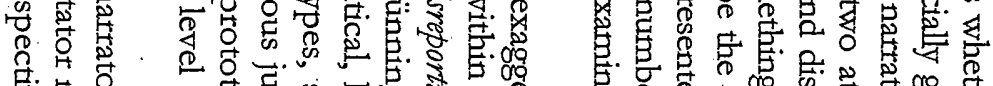

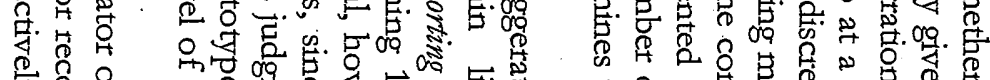

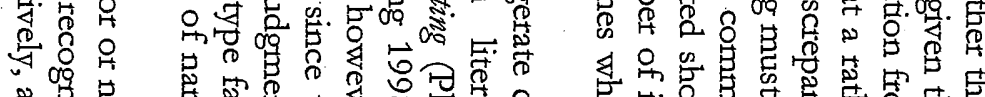

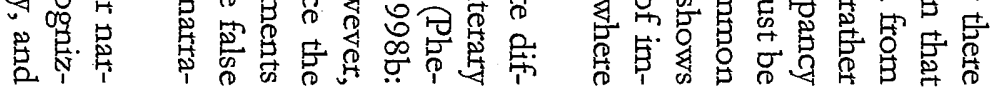

ง 
岕

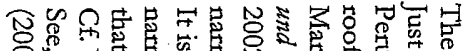

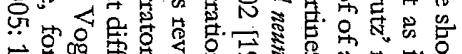

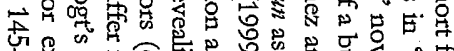

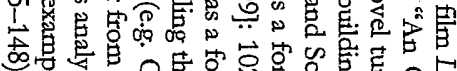

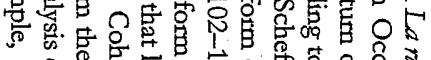

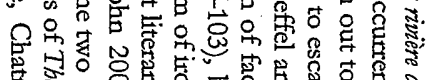

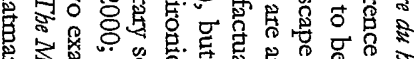

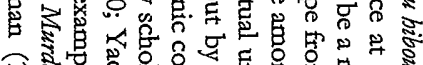

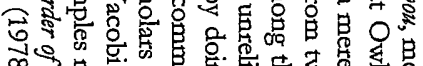

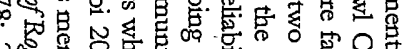

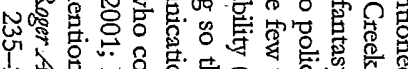

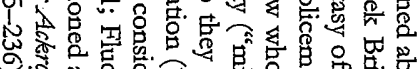

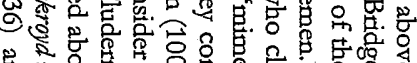

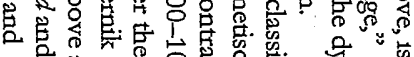

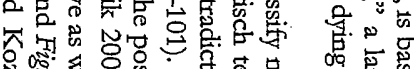

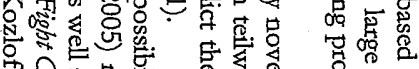

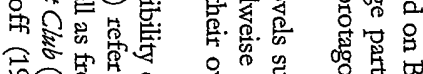

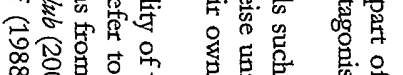

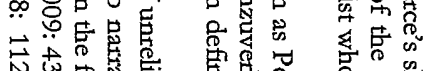

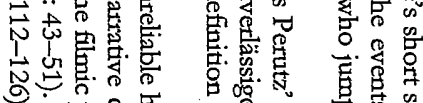

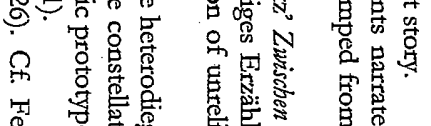

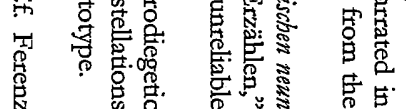

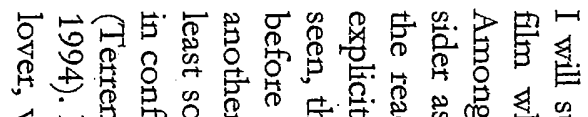

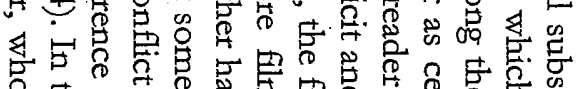

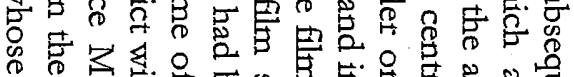

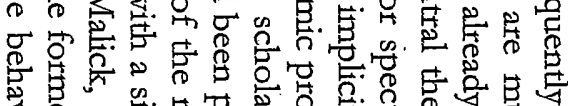

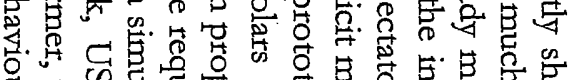

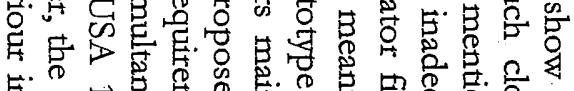

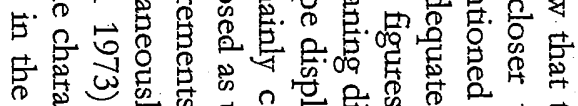

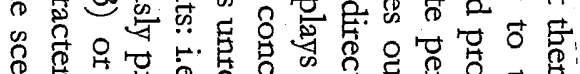

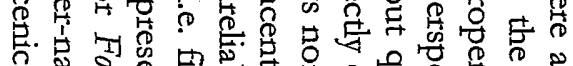

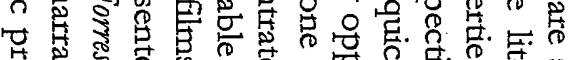

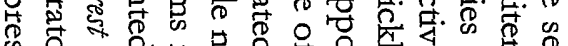

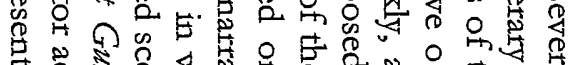

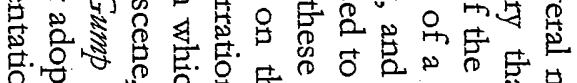

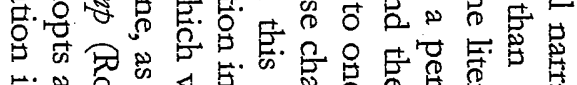

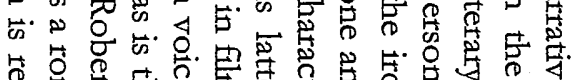

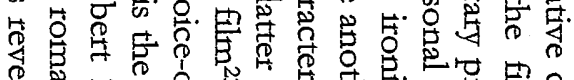

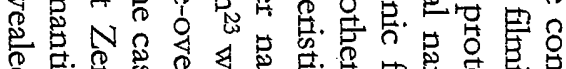

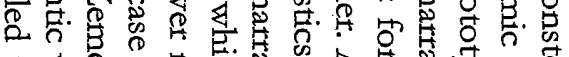

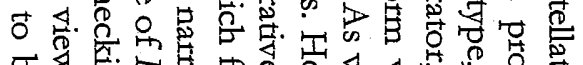

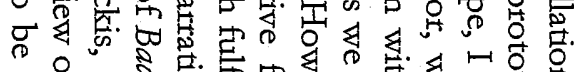

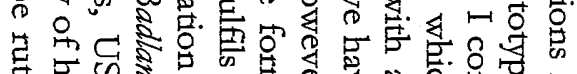

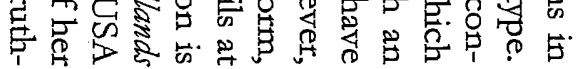

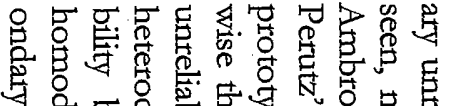

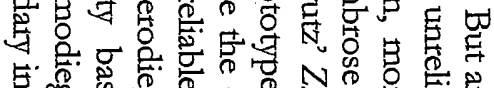

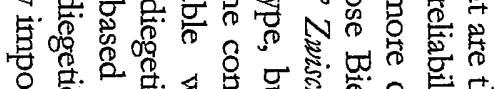

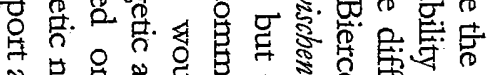

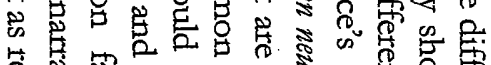

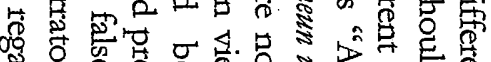

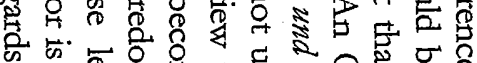

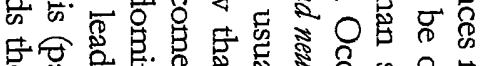

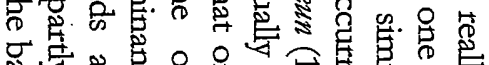

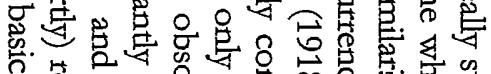

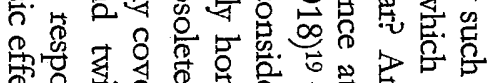

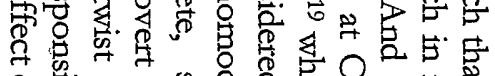

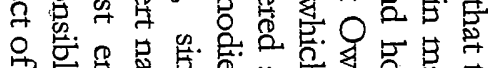

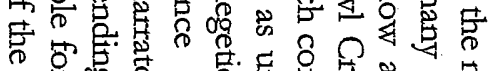

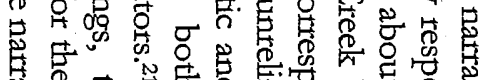

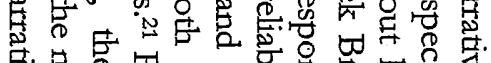

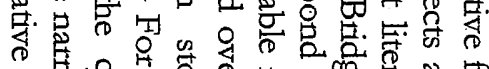

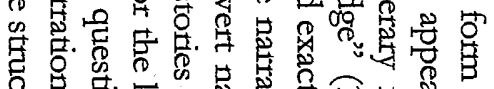

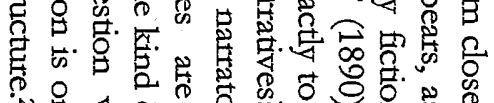

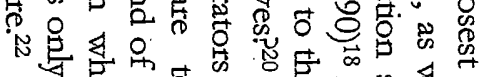

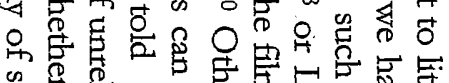

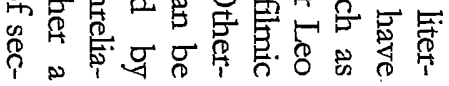

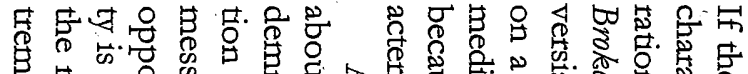

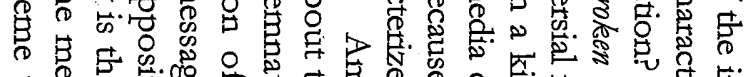

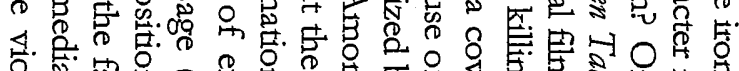

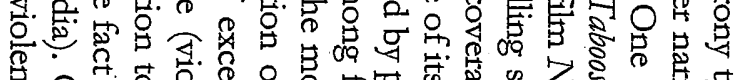

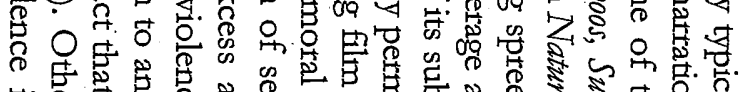

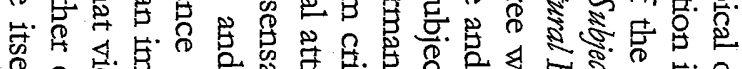

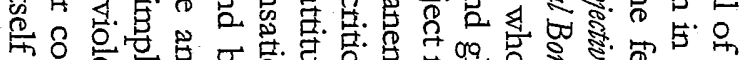

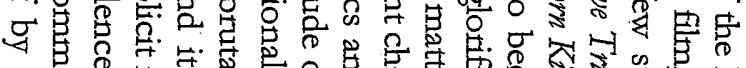

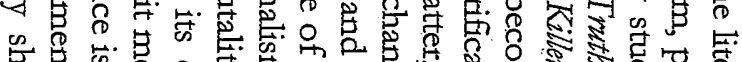

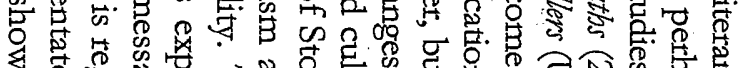

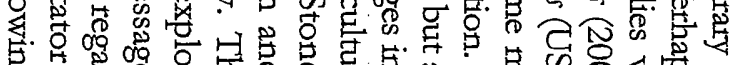

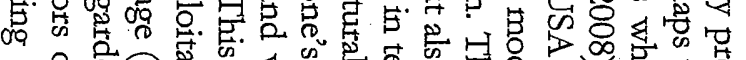

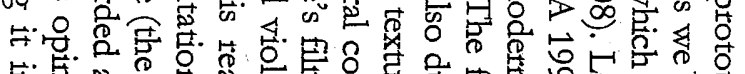

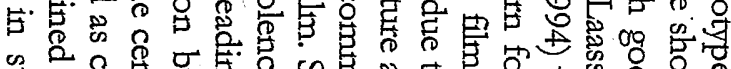

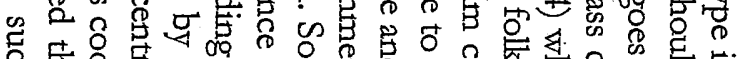

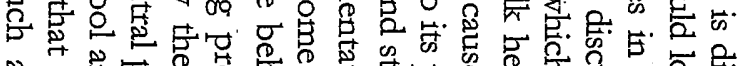

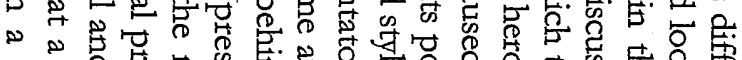

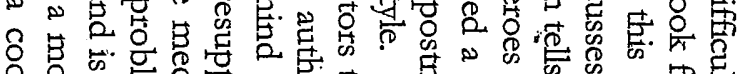

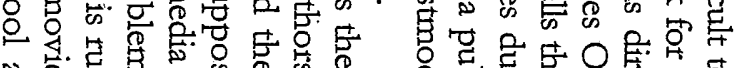

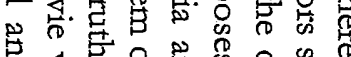

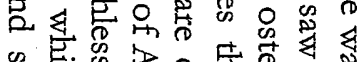

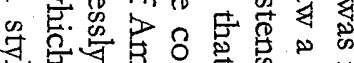

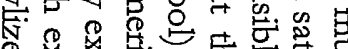

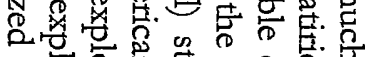

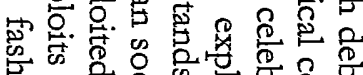
管.

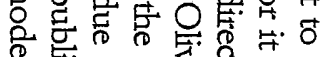

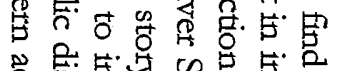

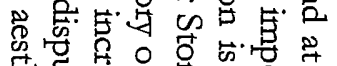

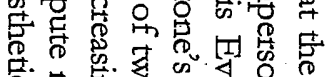

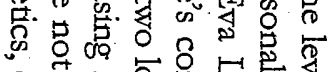

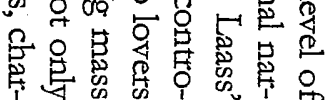

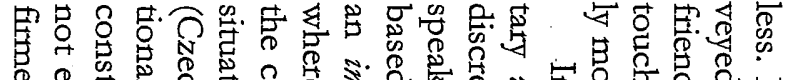

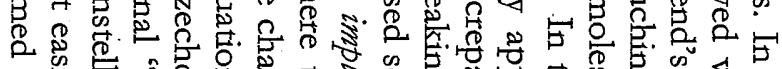

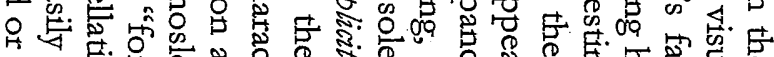

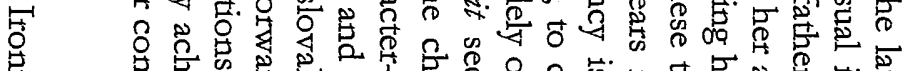

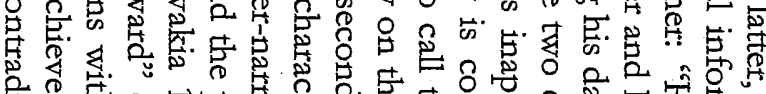

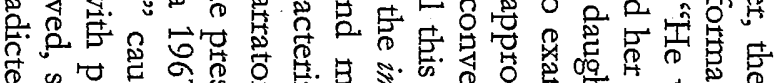

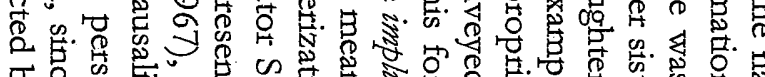

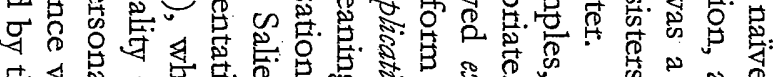

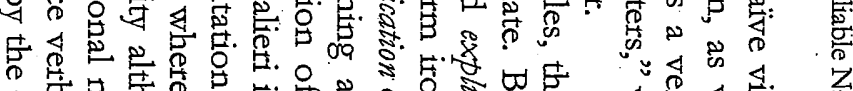

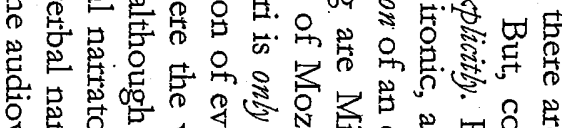

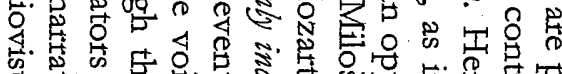

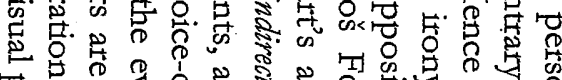

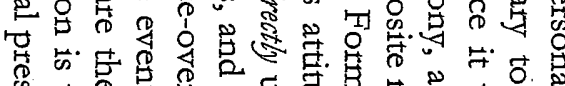

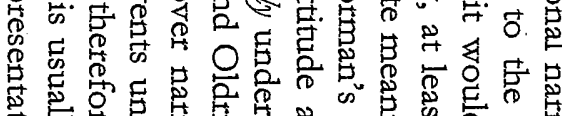

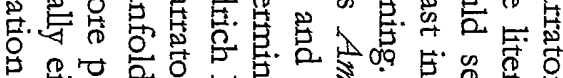

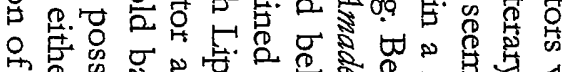

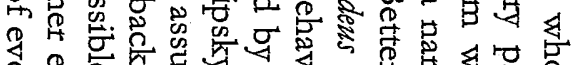

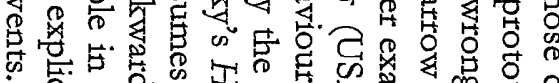

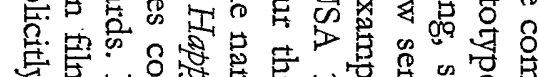

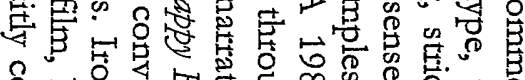

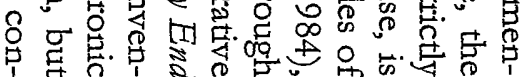

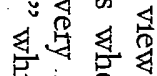

客实昌。

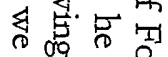

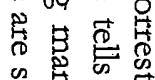

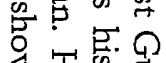

要要

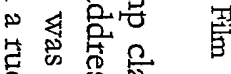

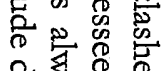

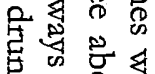

武总点

员孯屋

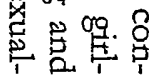




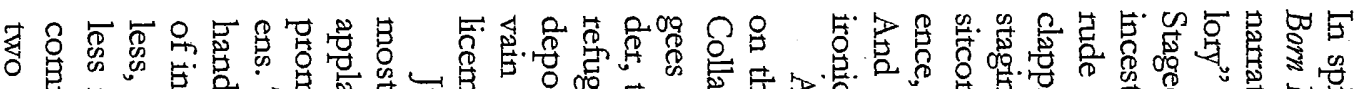

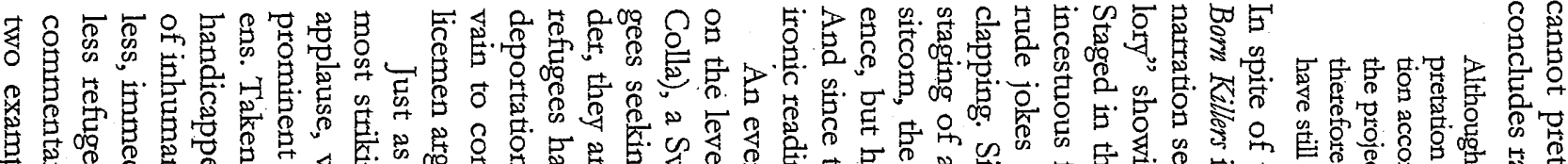

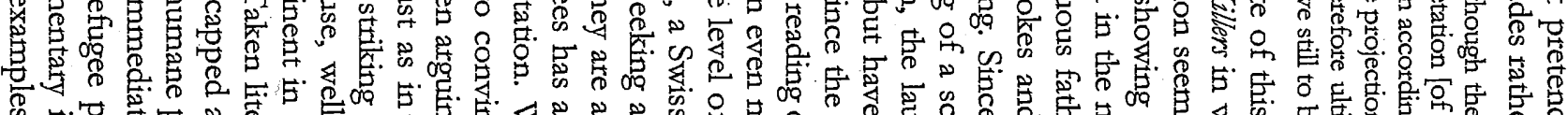

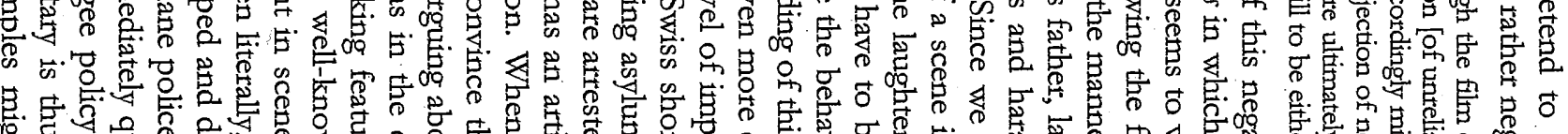

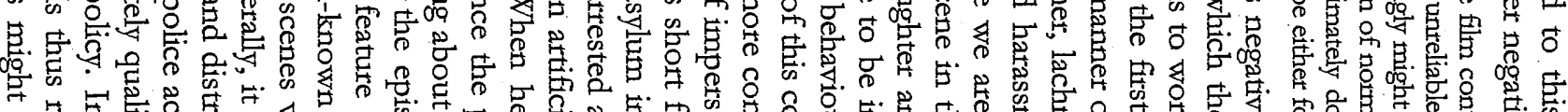

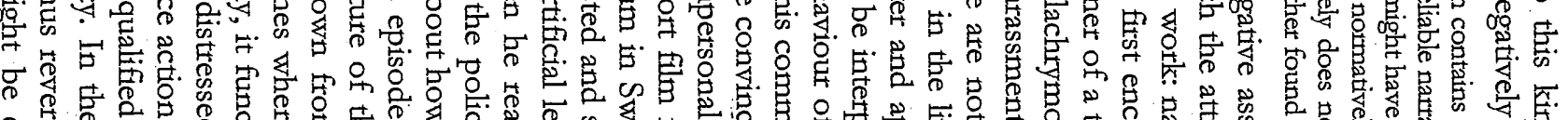

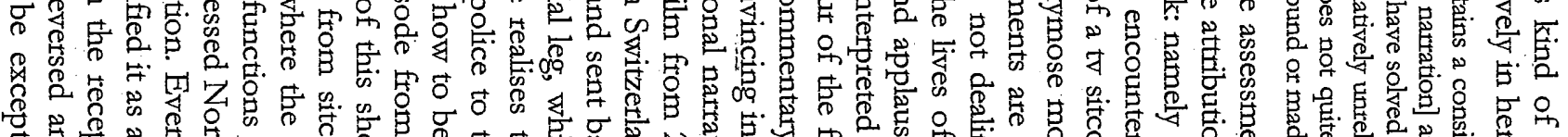

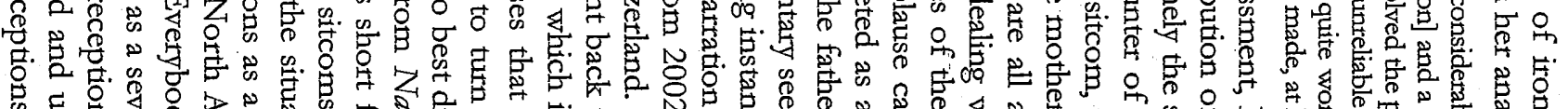

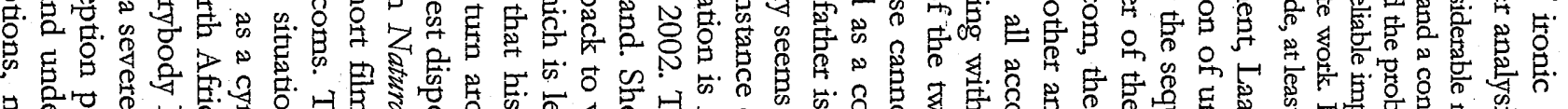

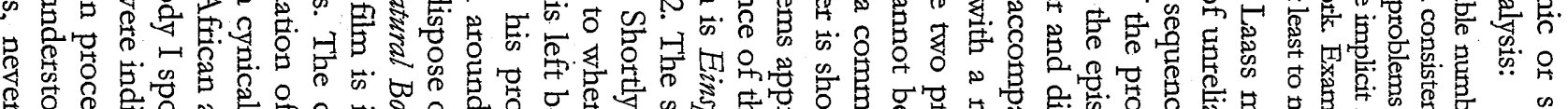

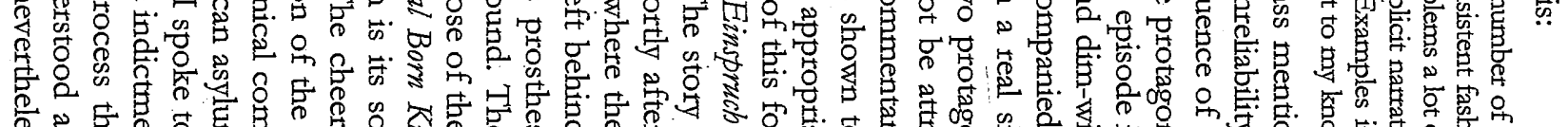

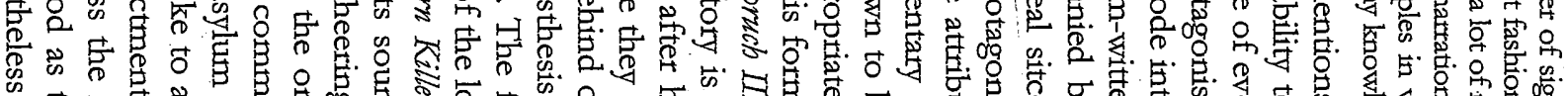

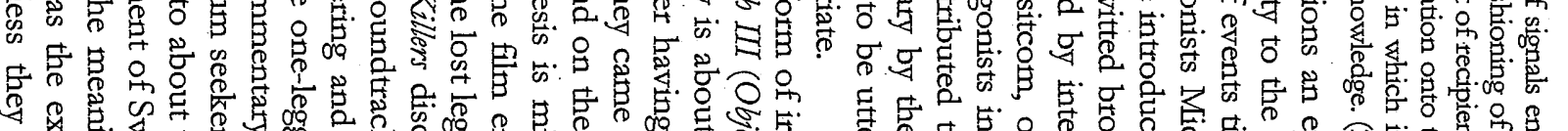

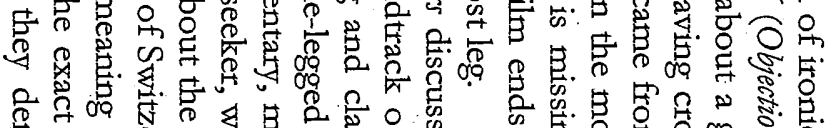

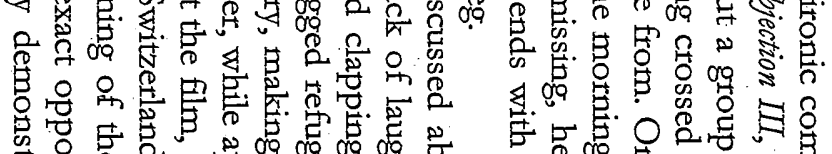

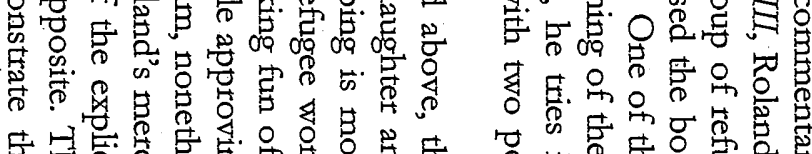

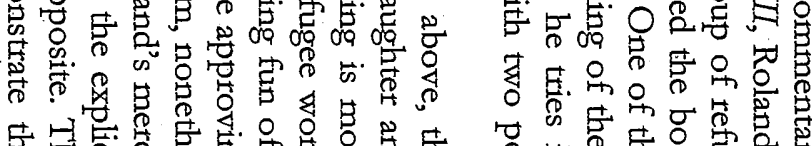

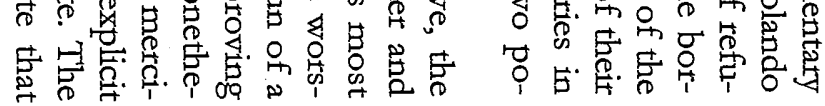

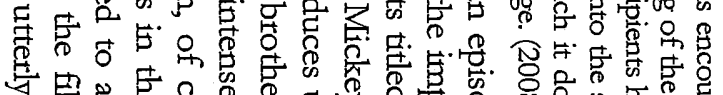

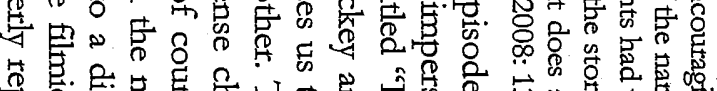

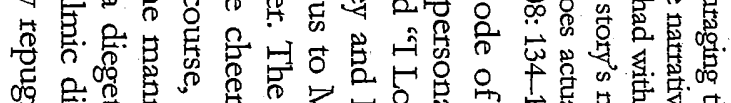

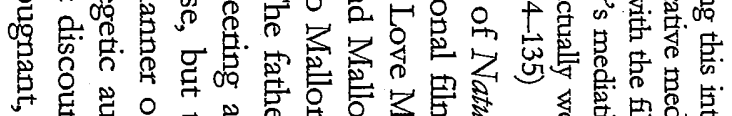

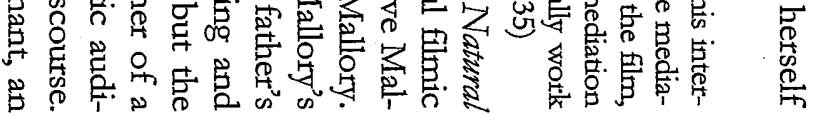

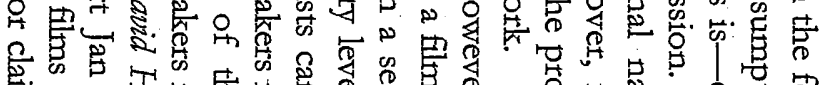

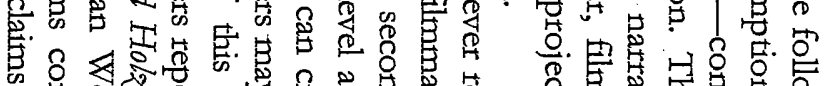

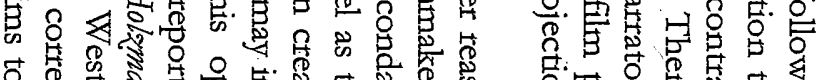

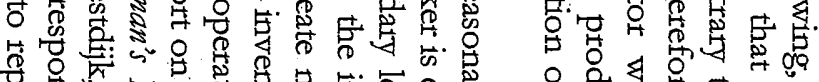

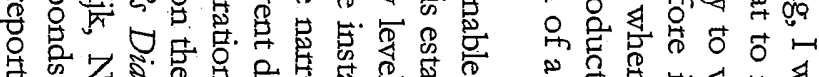

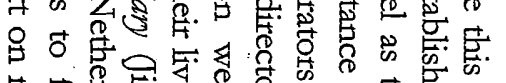

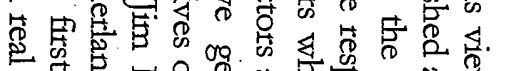

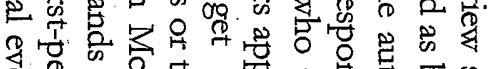

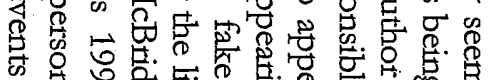

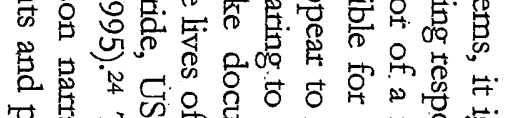

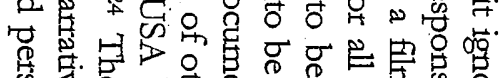

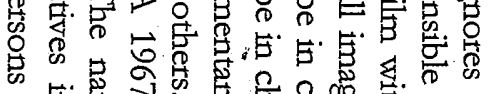

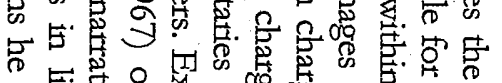

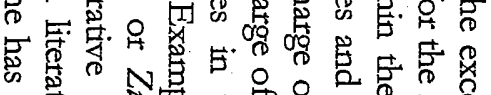

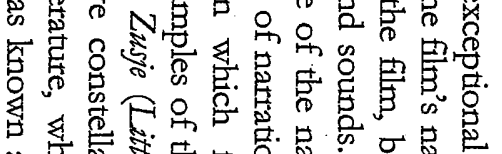

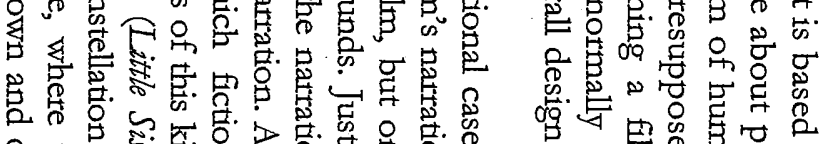
s.

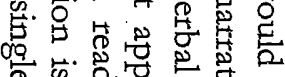

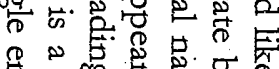

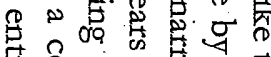

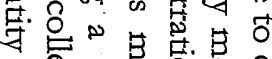

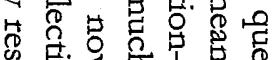

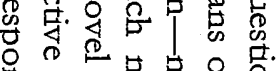

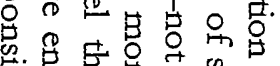

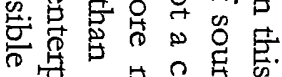

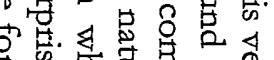

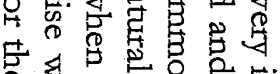

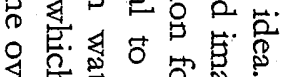

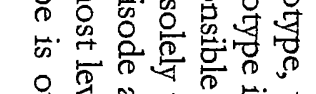

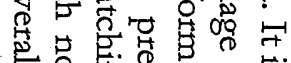

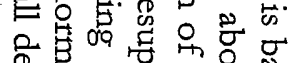

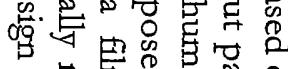

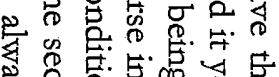

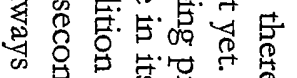

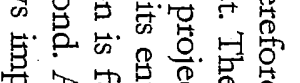

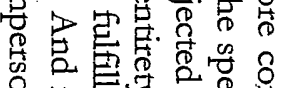

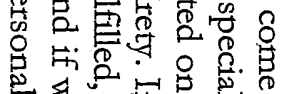

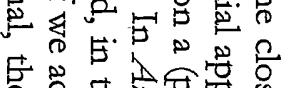

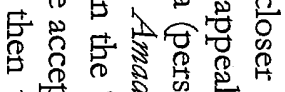

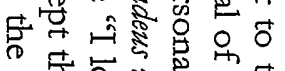
点害号总官官

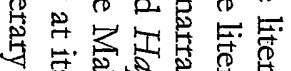

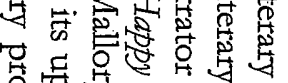

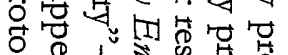

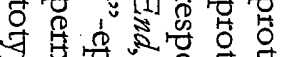
क क क o o

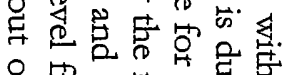

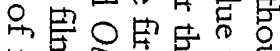

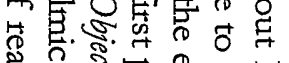

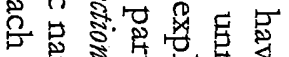

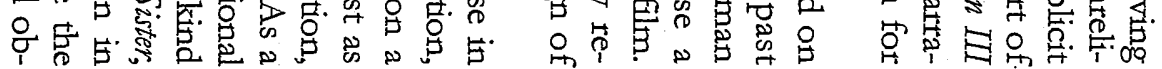




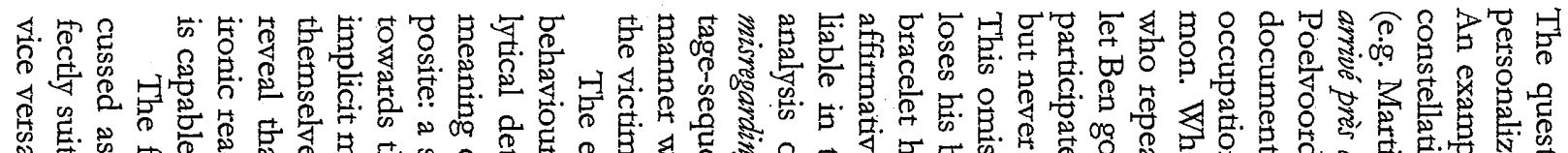

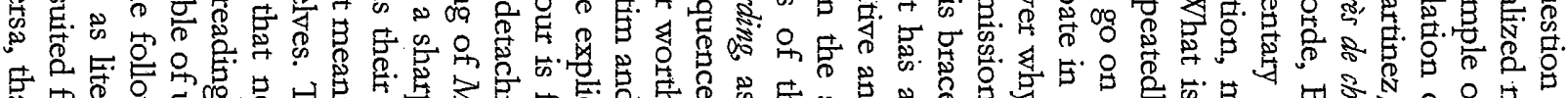

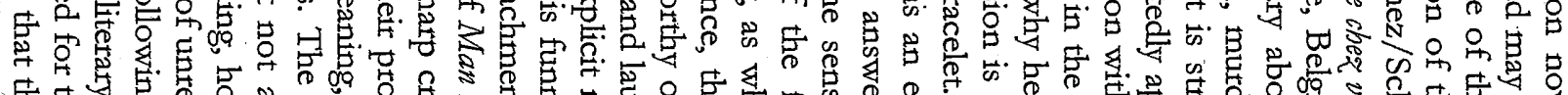

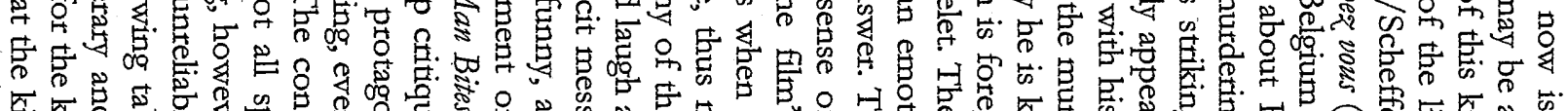

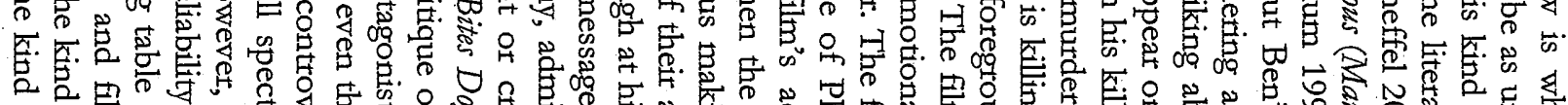

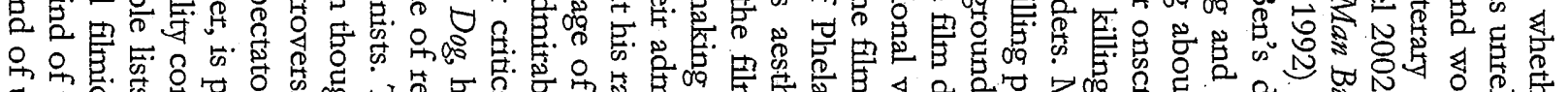

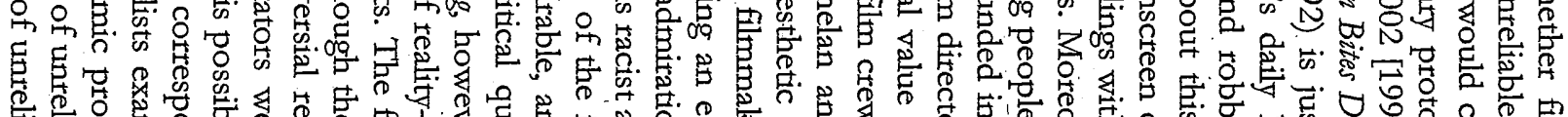

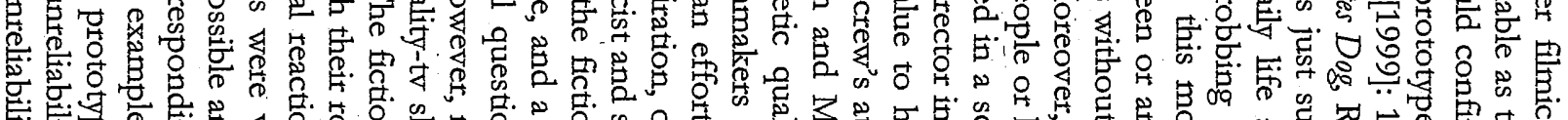

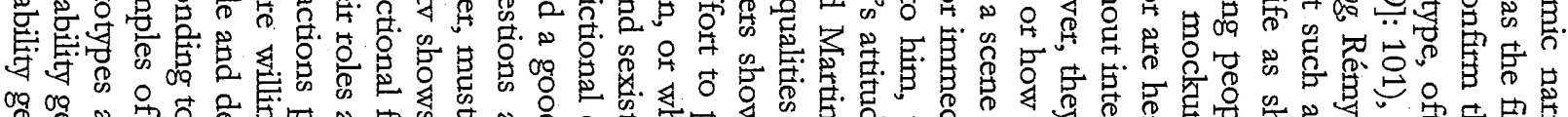

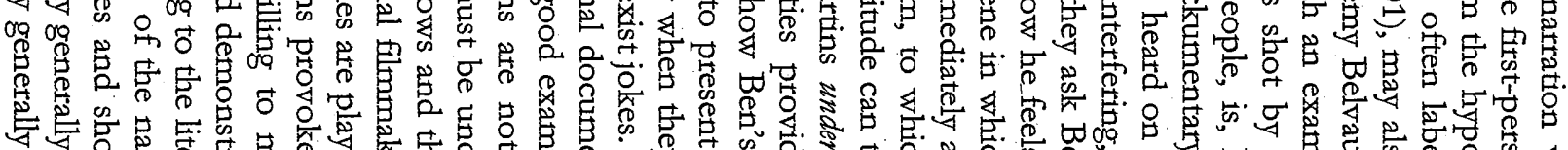

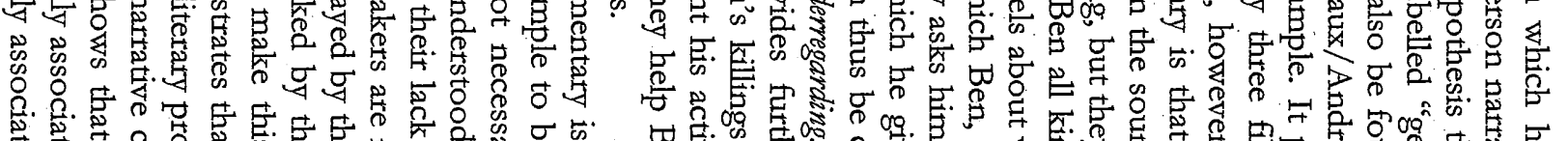

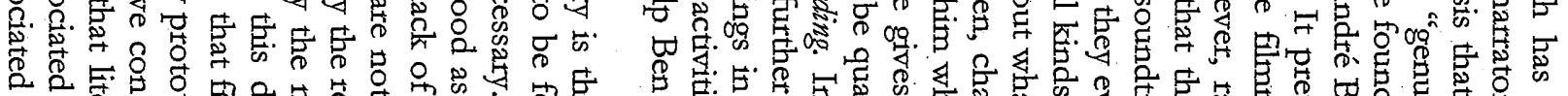

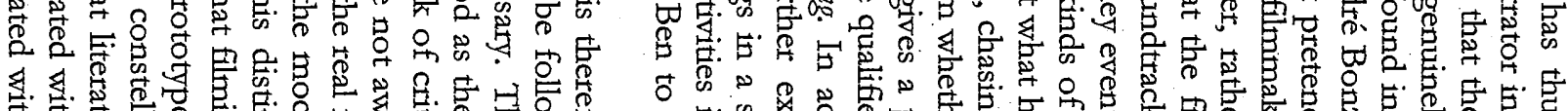

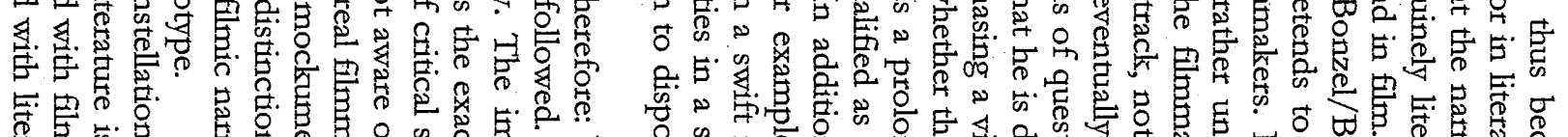

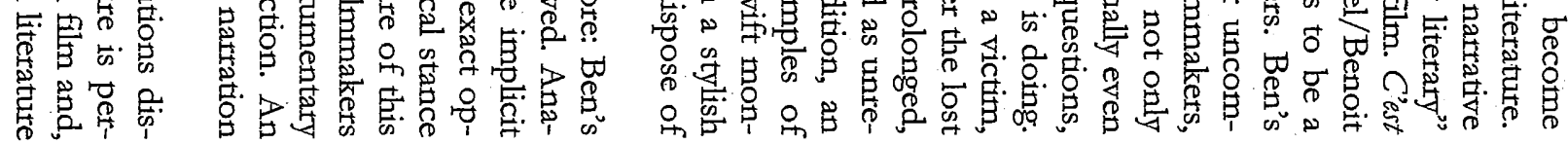

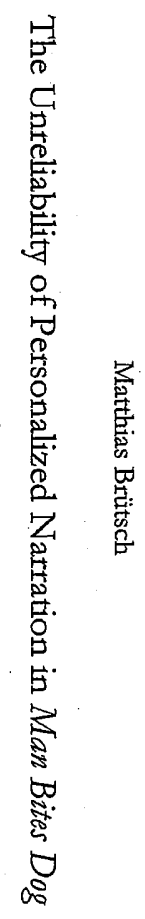

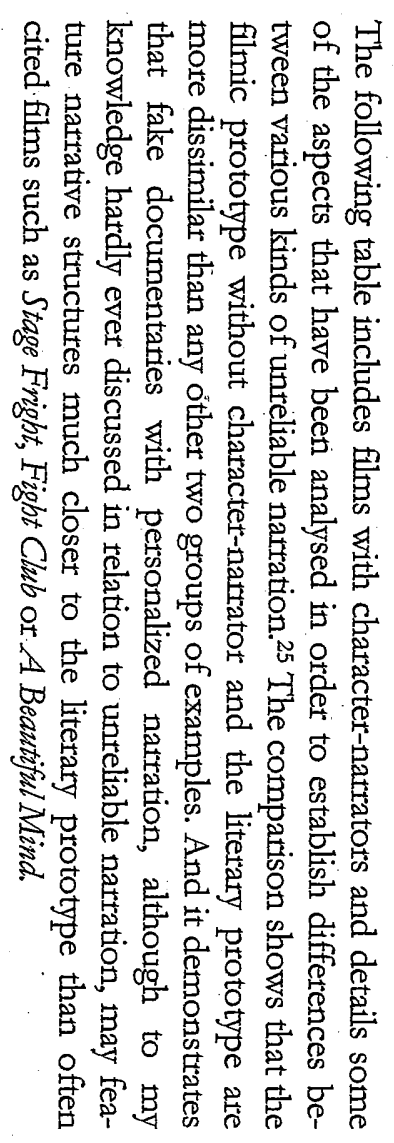

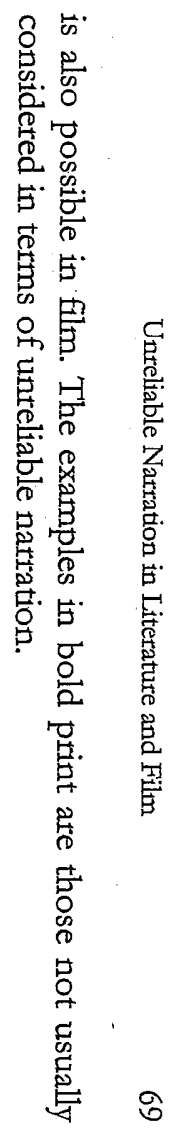




\begin{tabular}{|c|c|c|c|c|c|c|c|}
\hline $\begin{array}{l}\text { unreliable narra- } \\
\text { tion }\end{array}$ & literary prototype & & & & $\begin{array}{l}\text { (variant of filmic } \\
\text { prototype) }\end{array}$ & $\begin{array}{l}\text { (variant of filmic } \\
\text { prototype) }\end{array}$ & filmic prototype \\
\hline literature & $\begin{array}{l}\text { Huckeleberny Finn; } \\
\text { "Haircut," } \\
\text { "Dead as They } \\
\text { Come," }\end{array}$ & - & - & - & Fight Club (novel) & $\begin{array}{c}\text { The Murder of Roger } \\
\text { Ackroyd }\end{array}$ & $\begin{array}{l}\text { "An Occurrence at } \\
\text { Otwl Creek Bridge," } \\
\text { Zwischen neun und neun }\end{array}$ \\
\hline film & Man Bites Dog & $\begin{array}{l}\text { Einspruch III, } \\
\text { "I Love Mallory"- } \\
\text { episode }\end{array}$ & $\begin{array}{l}\text { Happy End, } \\
\text { Amadeus }\end{array}$ & $\begin{array}{l}\text { Badlands, } \\
\text { Forrest Gump }\end{array}$ & Fight Club (film) & $\begin{array}{c}\text { Stage Fright, } \\
\text { The Usual Suspeits }\end{array}$ & $\begin{array}{l}\text { La Rivuèr du Hibou, } \\
\text { The Sixth Sense, } \\
\text { A Beautiful Mind }\end{array}$ \\
\hline $\begin{array}{l}\text { personalized } \\
\text { narration }\end{array}$ & yes & no & only partly & only partly & $\begin{array}{l}\text { literature: yes; } \\
\text { film: only partly }\end{array}$ & $\begin{array}{l}\text { literature: yes, } \\
\text { film: only partly }\end{array}$ & no \\
\hline $\begin{array}{l}\text { alternative } \\
\text { version explicitly }\end{array}$ & no & no & no & yes & yes & yes & yes \\
\hline $\begin{array}{l}\text { early/gradual } \\
\text { revelation of } \\
\text { unreliability } \\
\end{array}$ & yes & yes & yes & yes & no & no & no \\
\hline $\begin{array}{l}\text { Is the read- } \\
\text { er/spectator } \\
\text { given false leads? }\end{array}$ & no & no & no & no & yes & yes & yes \\
\hline $\begin{array}{l}\text { Is the character- } \\
\text { narrator lying/ } \\
\text { deceiving? }\end{array}$ & no & - & no & no & no & yes & - \\
\hline $\begin{array}{l}\text { distribution of } \\
\text { knowledge } \\
\text { (>: knows more } \\
\text { than; =: knows } \\
\text { the same as; < } \\
\text { knows less than) }\end{array}$ & $\begin{array}{l}\text { reader }>\text { narra- } \\
\text { tor/spectator }> \\
\text { personalized narra- } \\
\text { tion }\end{array}$ & $\begin{array}{l}\text { spectator }= \\
\text { narration }> \\
\text { characters }\end{array}$ & $\begin{array}{l}\text { spectator = narra- } \\
\text { tion > chamcter- } \\
\text { narrator }\end{array}$ & $\begin{array}{l}\text { spectator }= \\
\text { narration }> \\
\text { character- narra- } \\
\text { tor }\end{array}$ & $\begin{array}{l}\text { before plot twist: } \\
\text { spectator = charac- } \\
\text { ter-narrator as } \\
\text { experiencing I < } \\
\text { character-narrator as } \\
\text { narrating I }\end{array}$ & $\begin{array}{l}\text { before plot twist:: } \\
\text { reader < narrator/ } \\
\text { spectator < charac- } \\
\text { ter-narrator }\end{array}$ & $\begin{array}{l}\text { before plot twist: } \\
\text { reader/spectator }= \\
\text { character }< \\
\text { heterodiegetic narra- } \\
\text { tor/ } \\
\text { impersonal narration }\end{array}$ \\
\hline
\end{tabular}

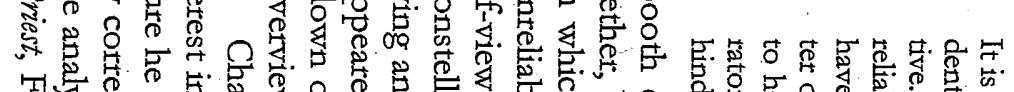

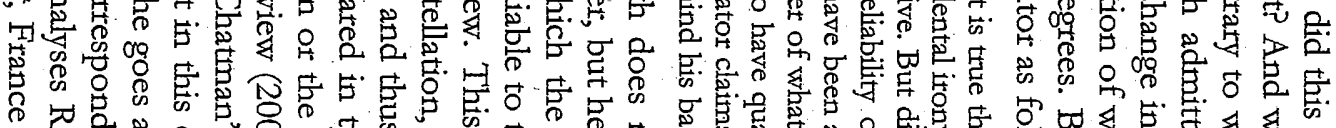

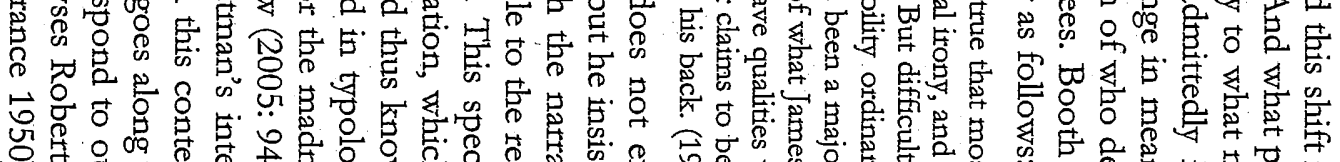

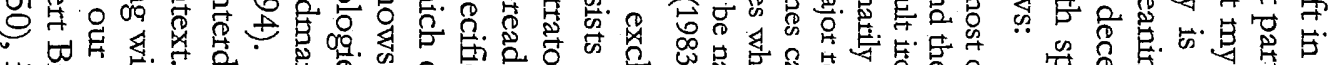

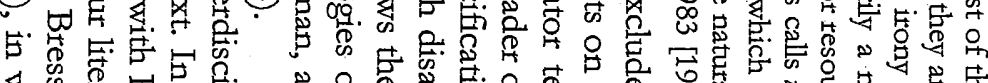

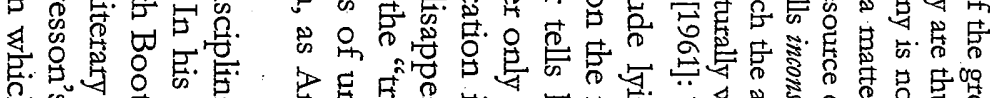

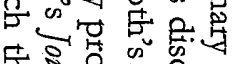

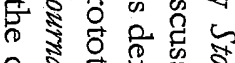

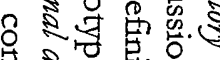

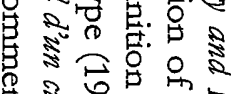

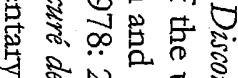

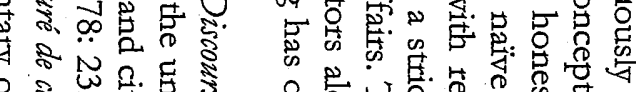

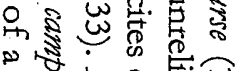

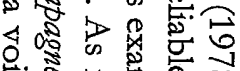
잉

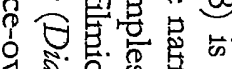

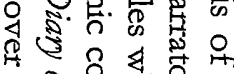

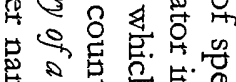

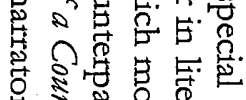

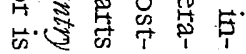

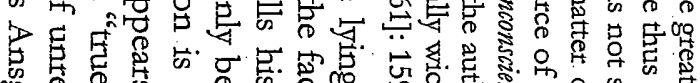

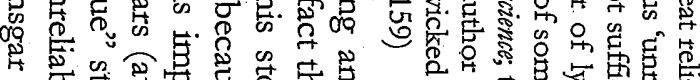

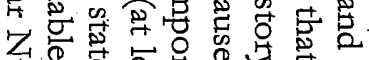

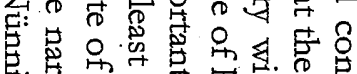

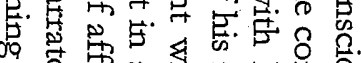
等

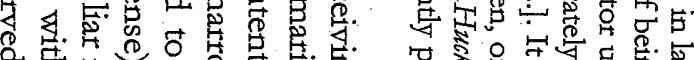

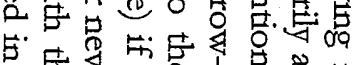

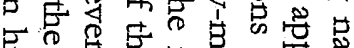
E. 与

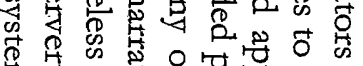

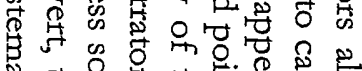

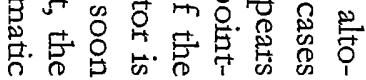

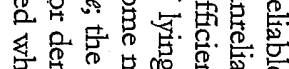

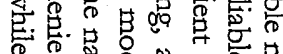

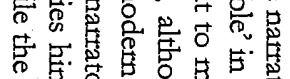

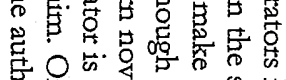

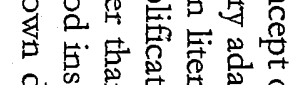

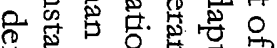

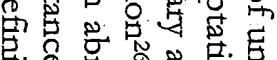

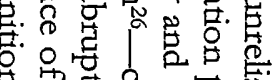

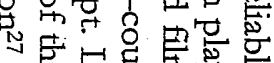

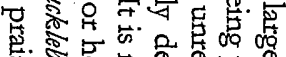

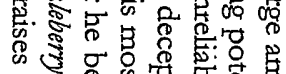

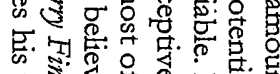

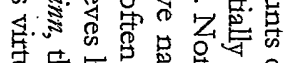

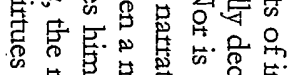

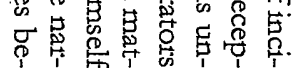




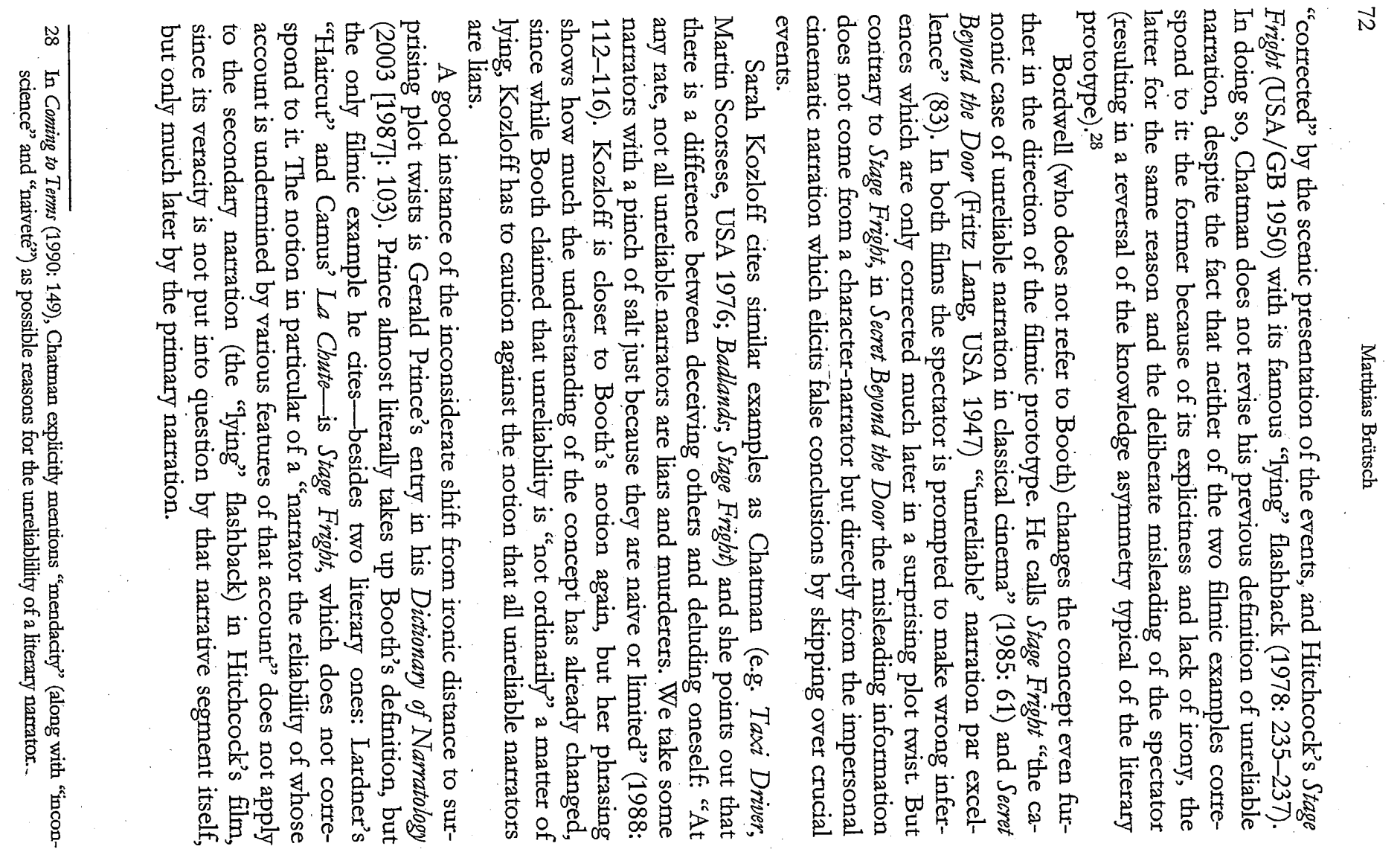

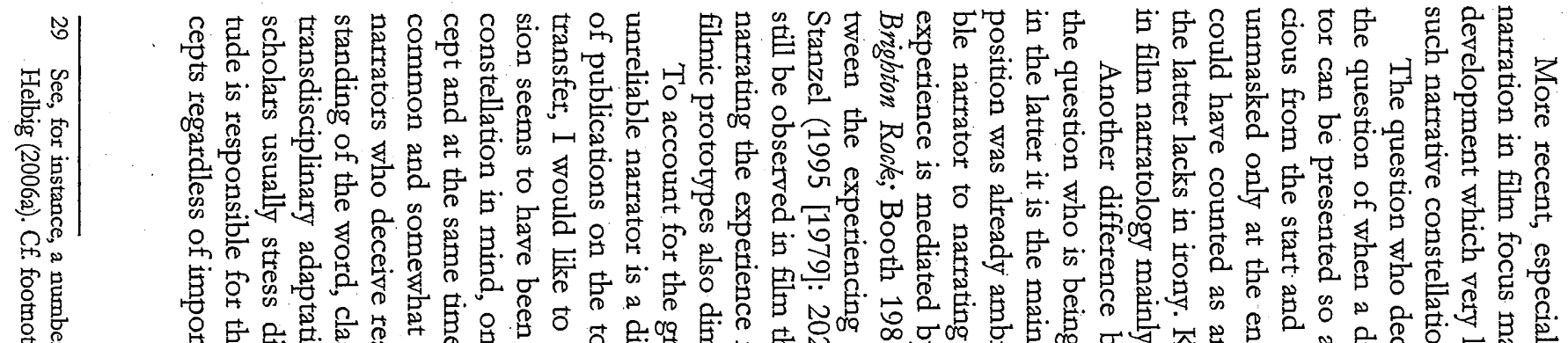

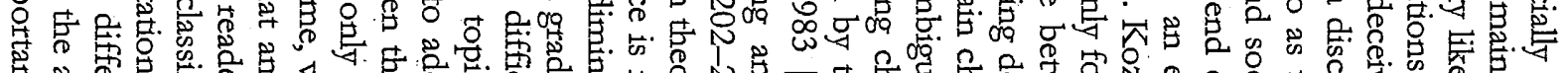

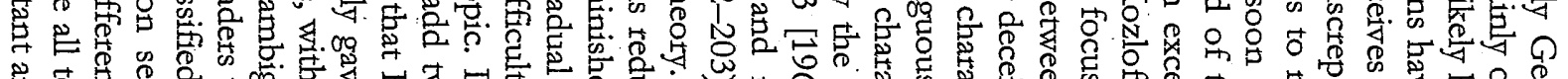

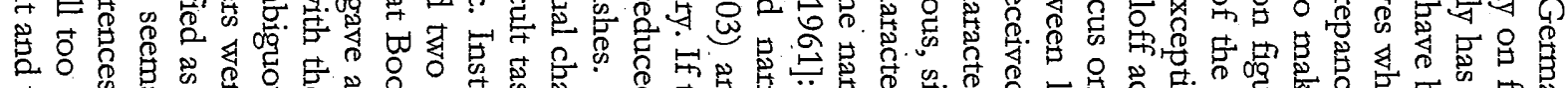

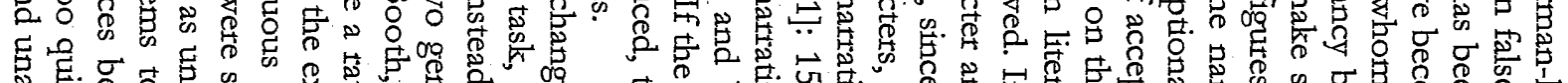

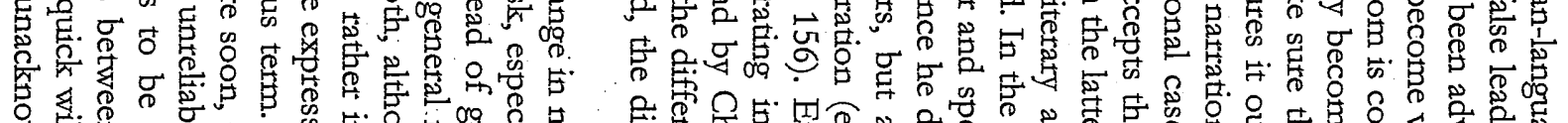

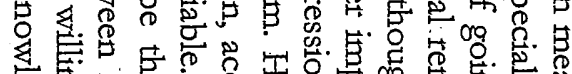

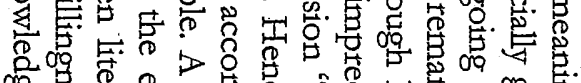

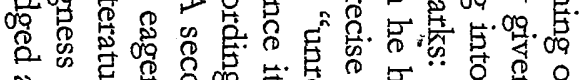

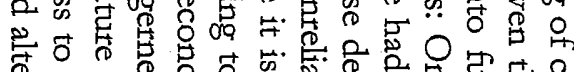

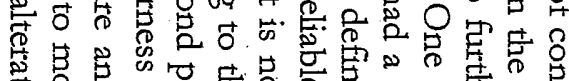

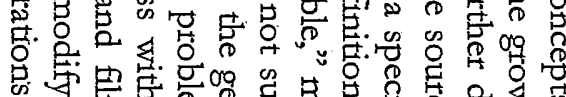

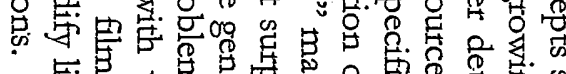

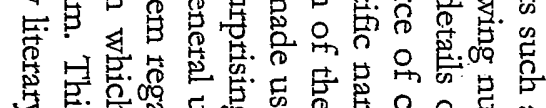

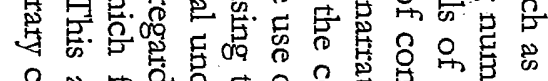

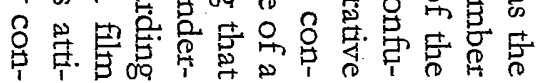
事 09.

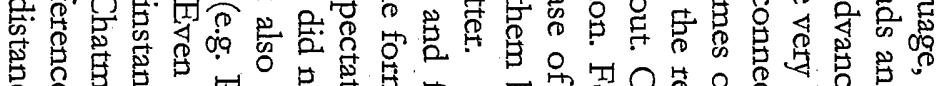

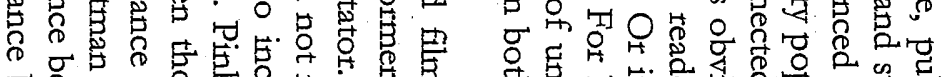

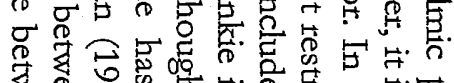

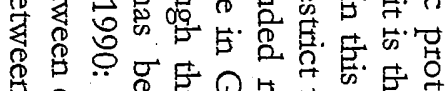

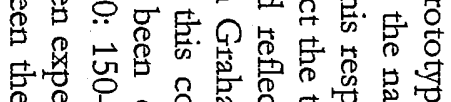

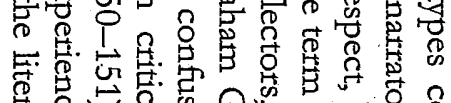

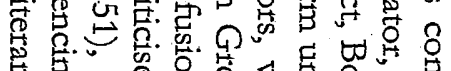

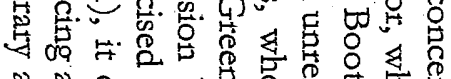

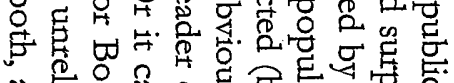

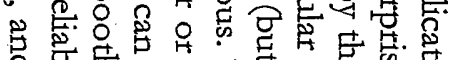

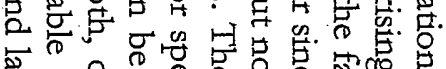

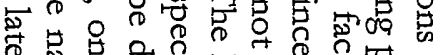

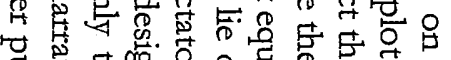

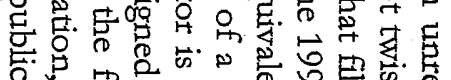

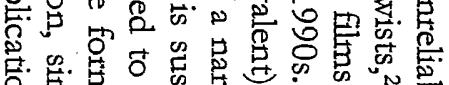

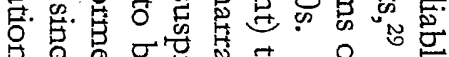




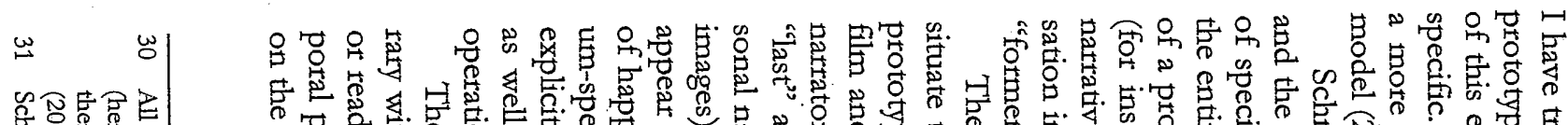

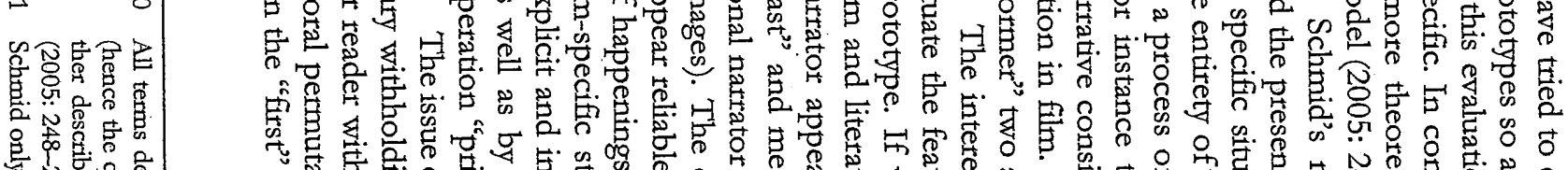

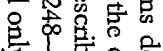

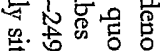

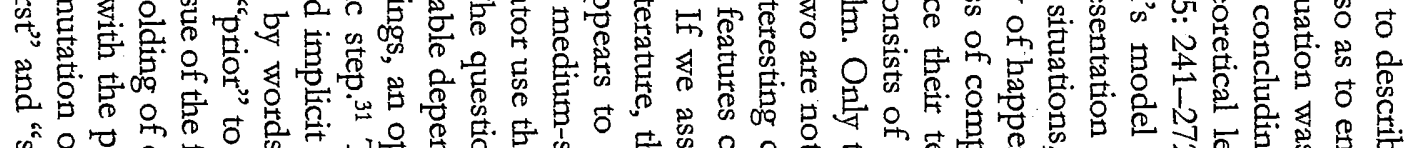
\&

究品

厍悹宫

包.

总记

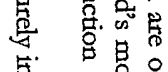

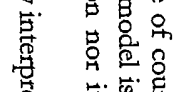

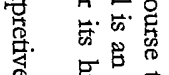

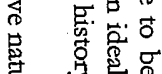

识

范蕰.

总客总

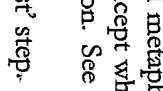

论宫

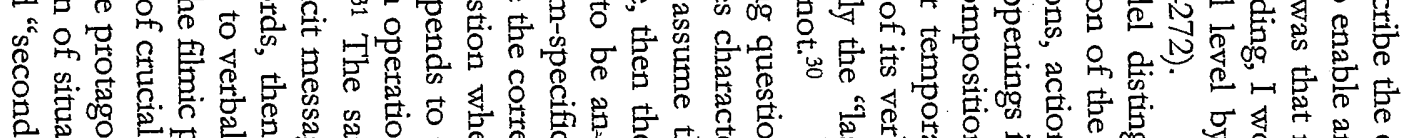

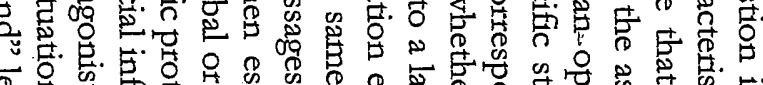

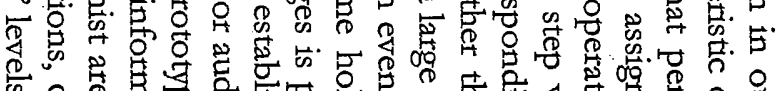

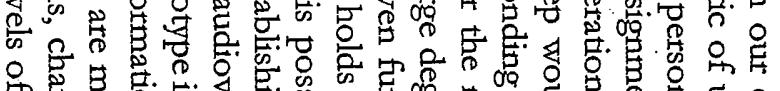

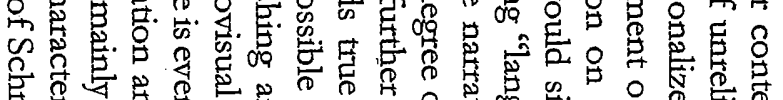

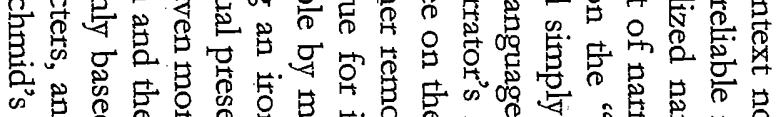

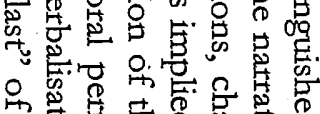

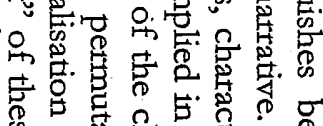

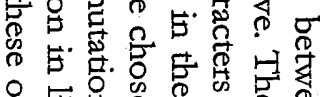

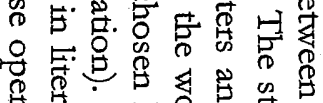

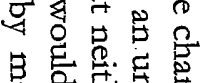

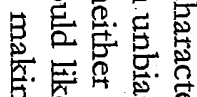

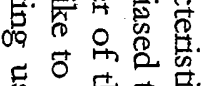

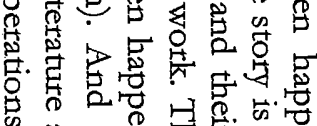

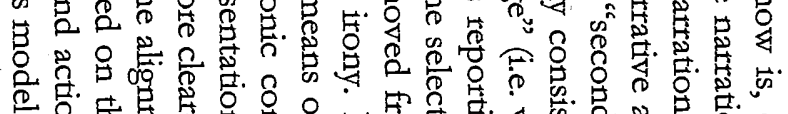

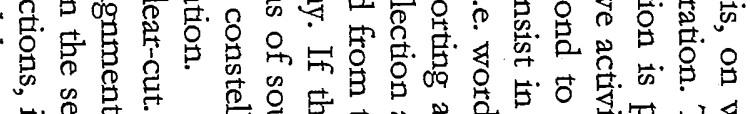

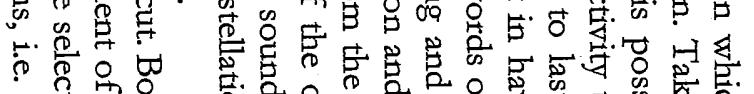

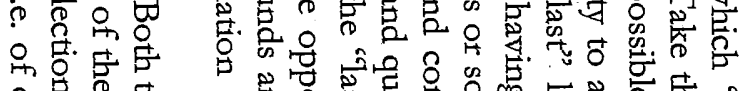

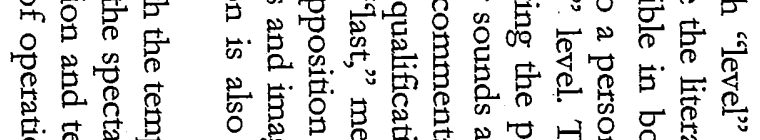

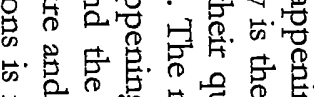

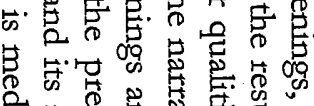

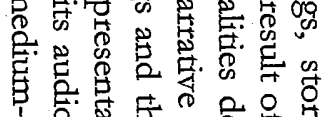

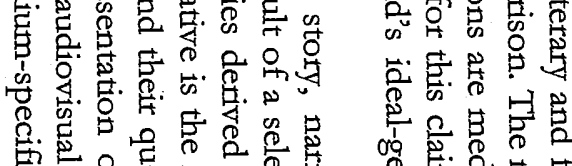

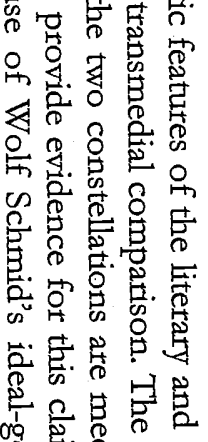

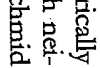
㩆留

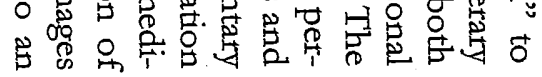

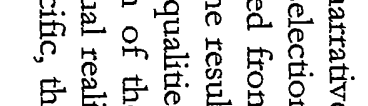

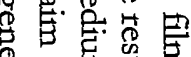

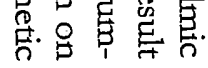

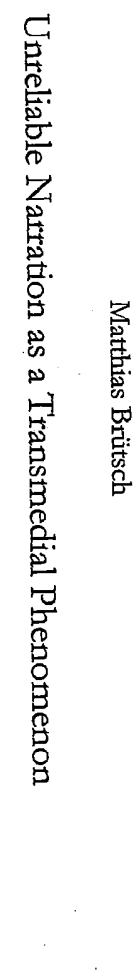

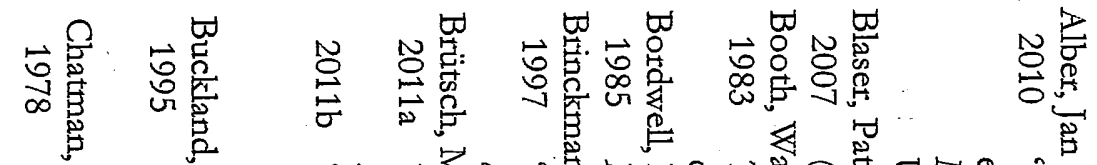

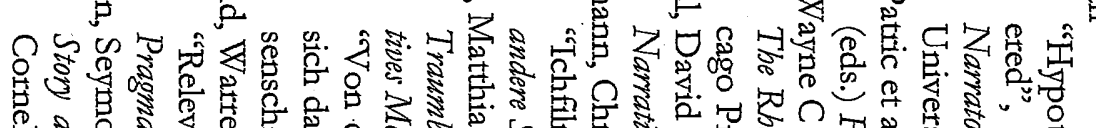

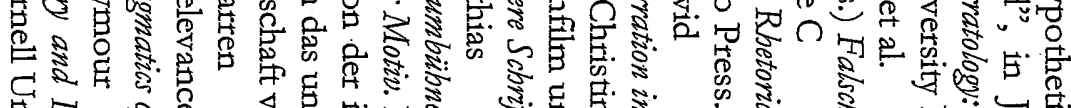

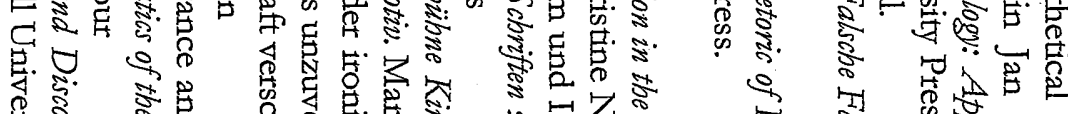

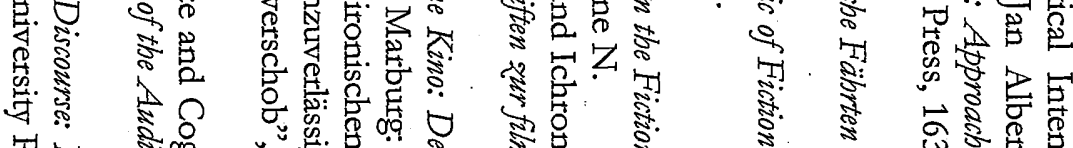

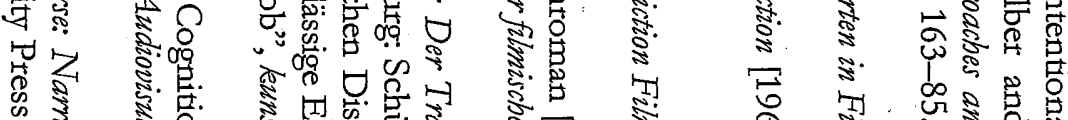

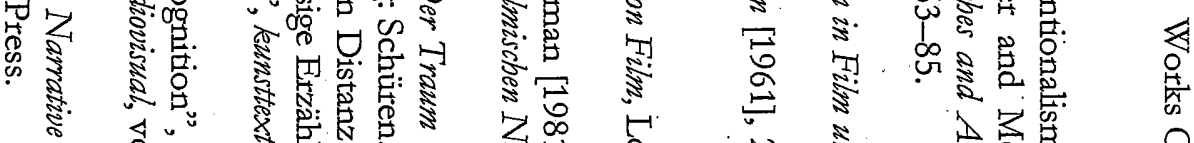

,

$\checkmark$

s.

s.

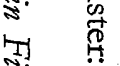

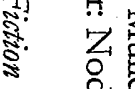

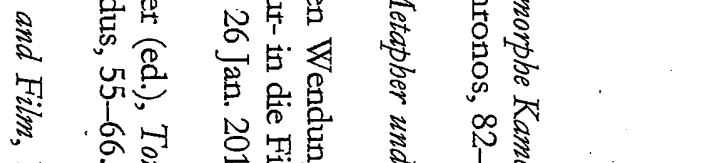

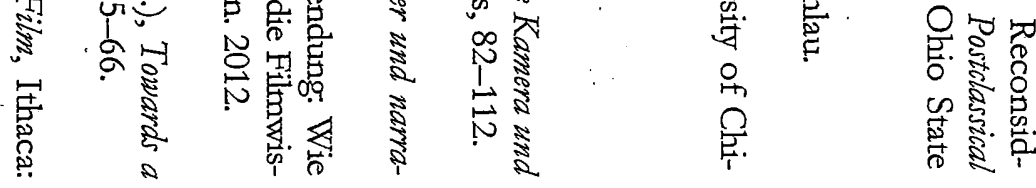




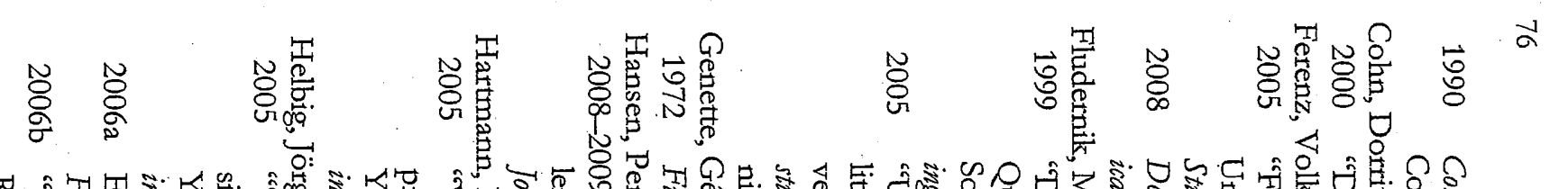

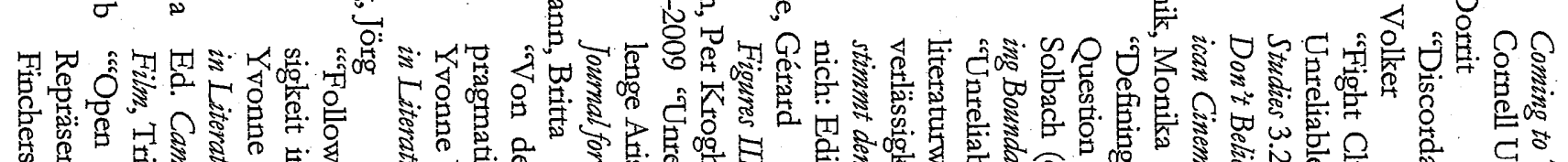

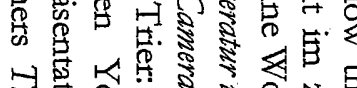

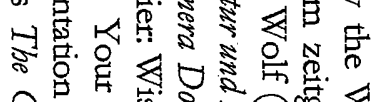
P:

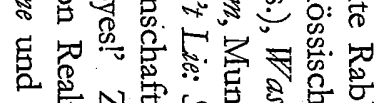

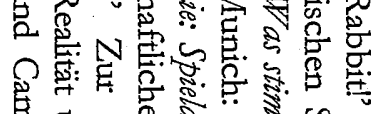

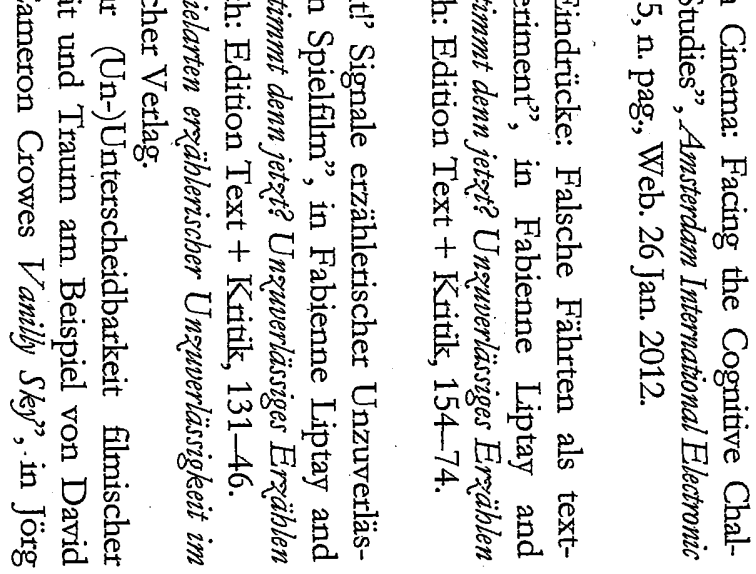

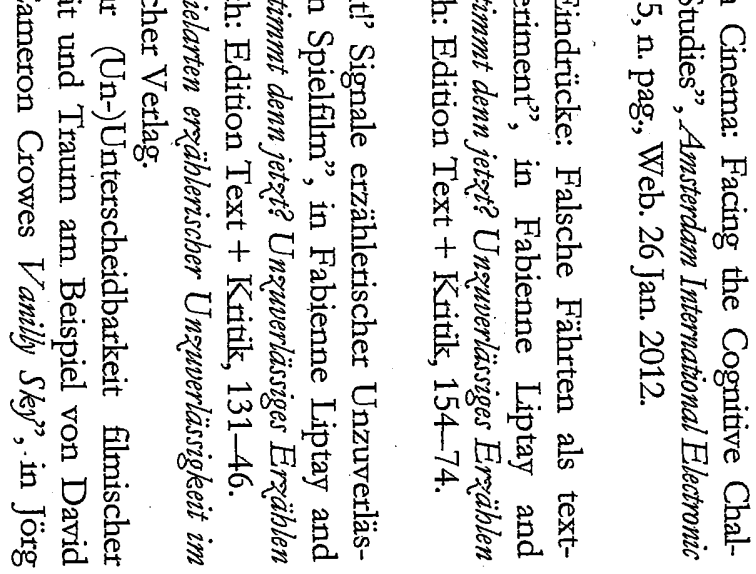

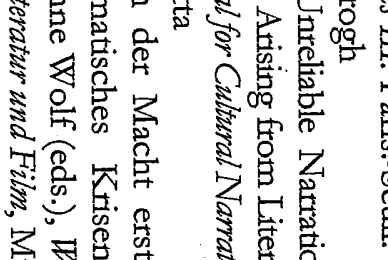

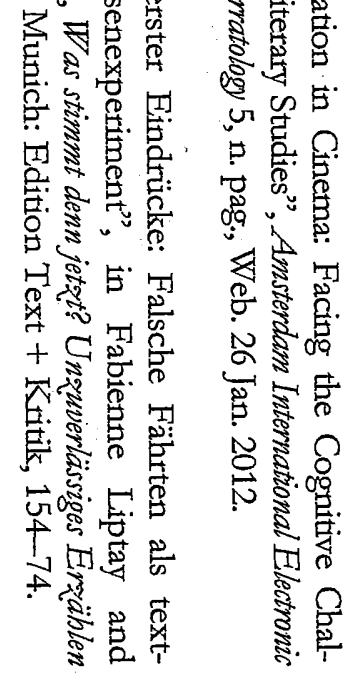

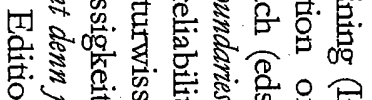

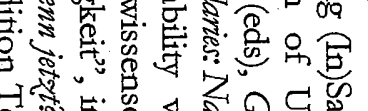

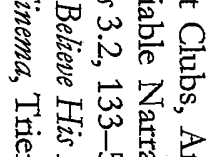

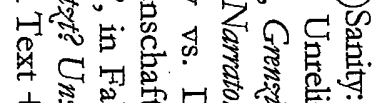

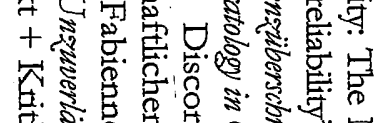

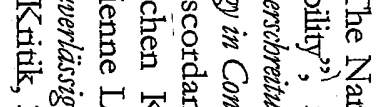

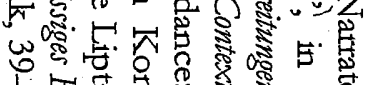

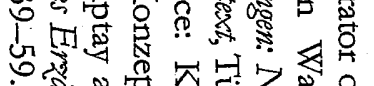

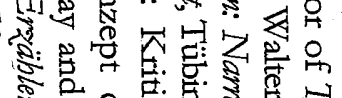

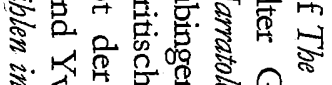

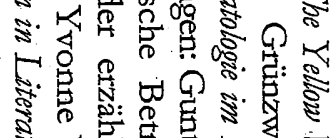

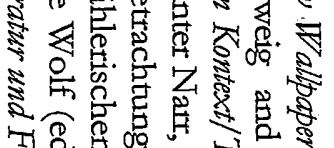

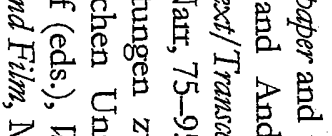

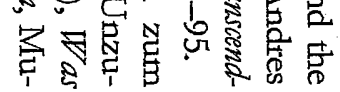

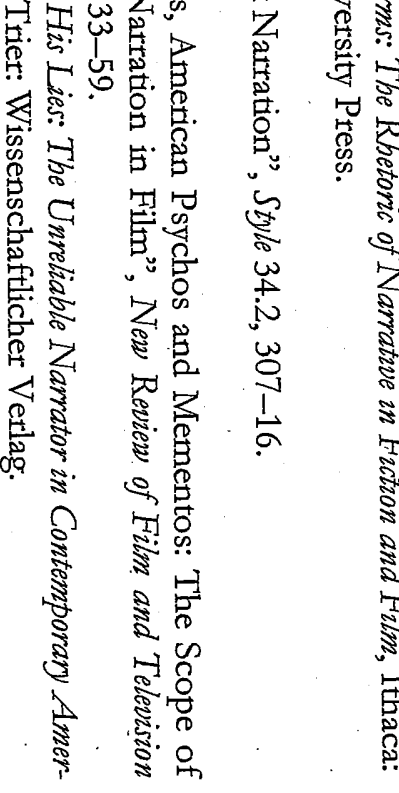

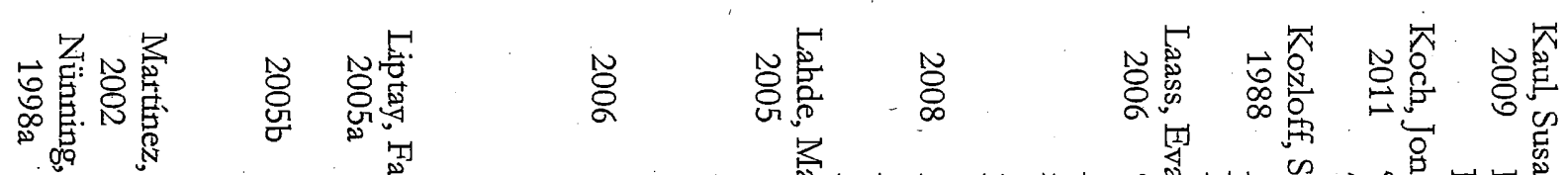

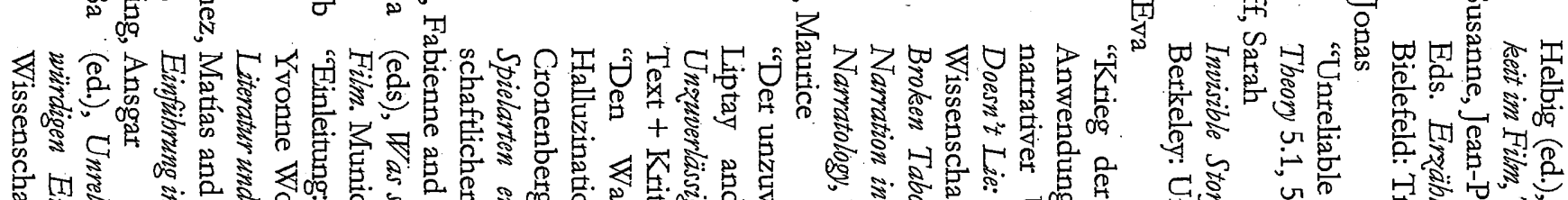

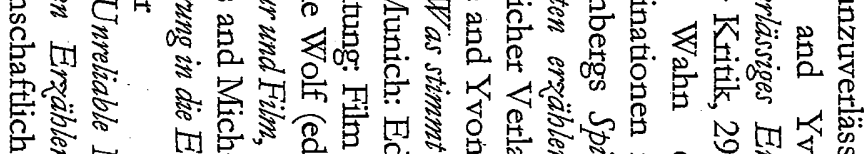

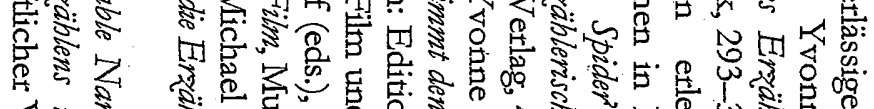

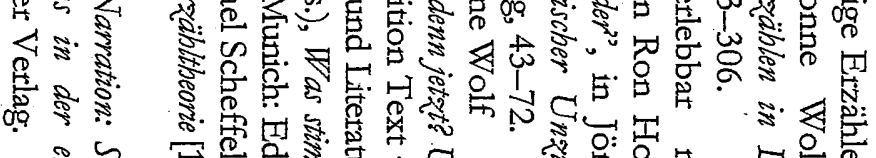

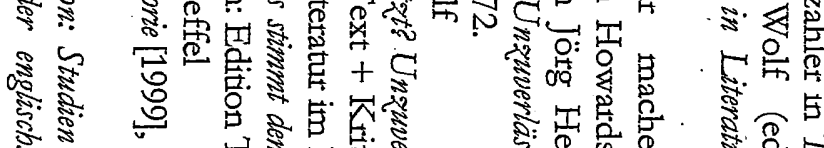

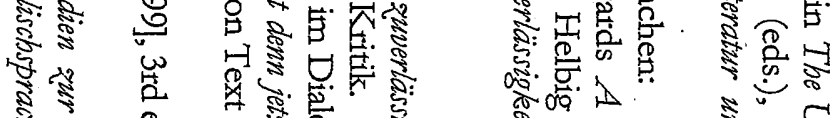

蛋

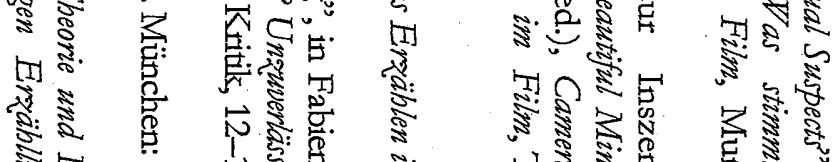

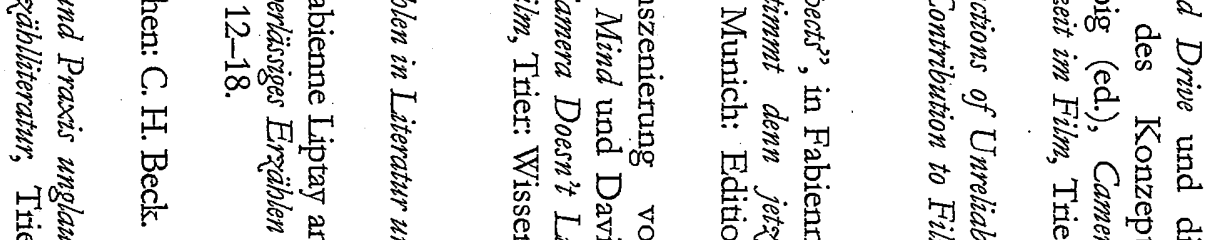

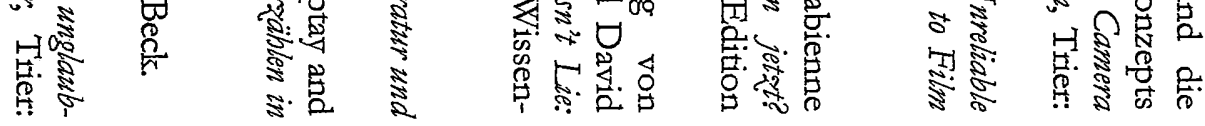

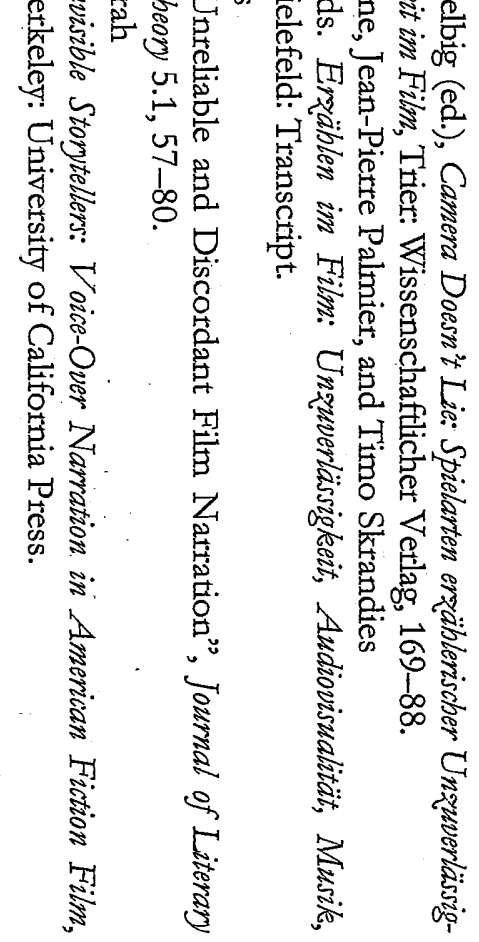

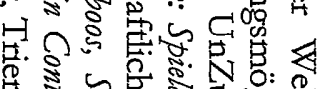

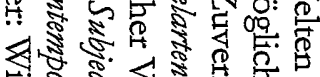

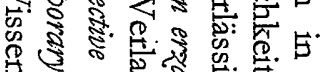

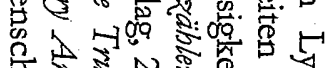

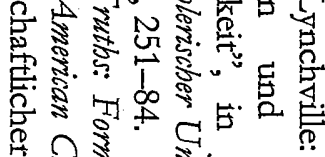

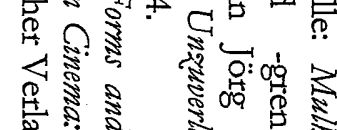

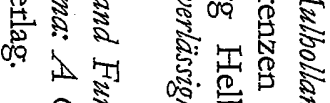
ค 吾 娄

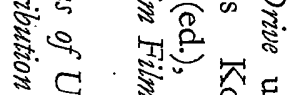




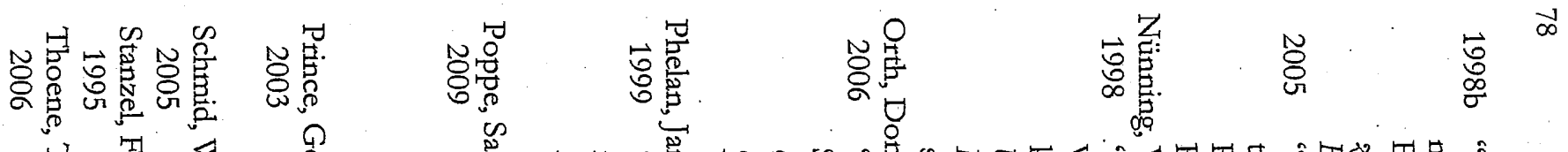

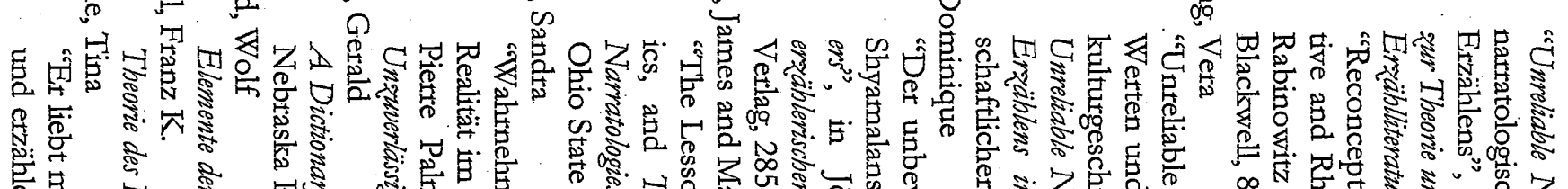

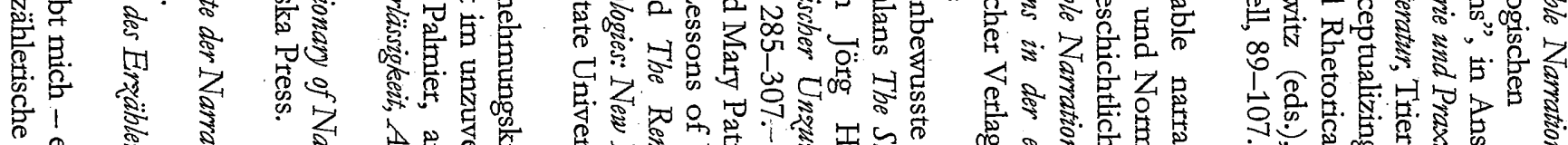

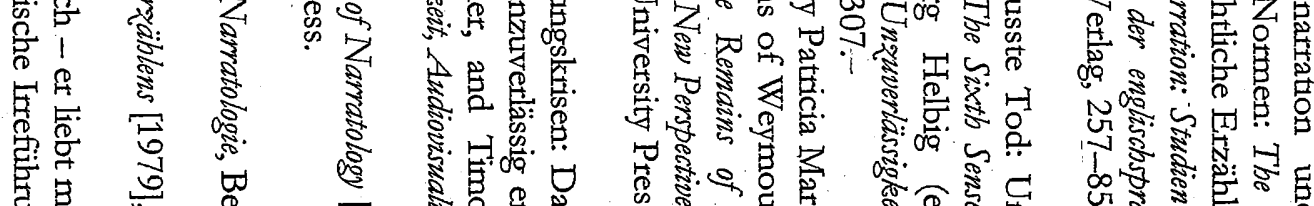

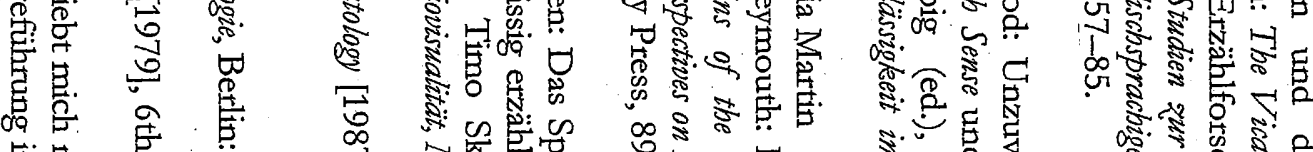

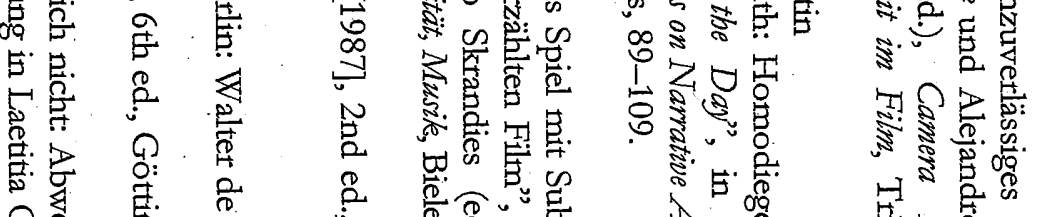

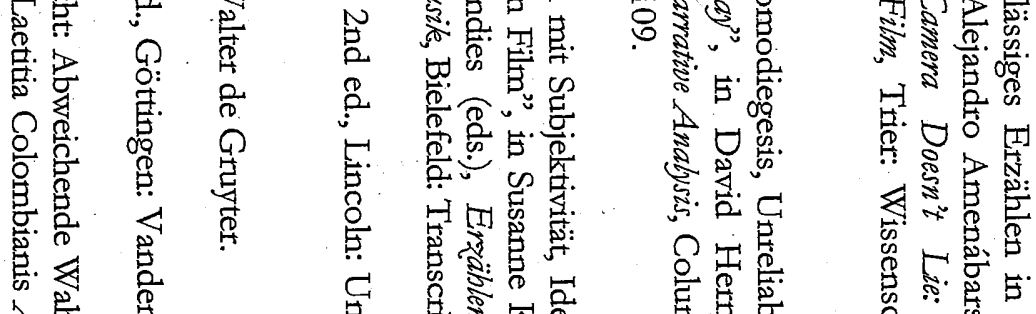

䔶

I)

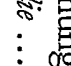

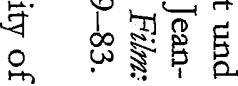

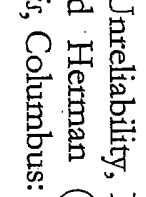

音臬思

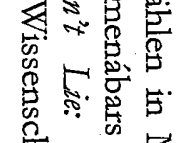

象象皆

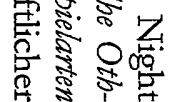

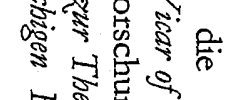

(1) क्षे.

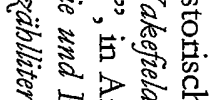

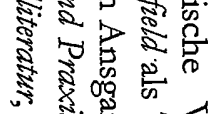

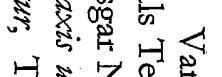

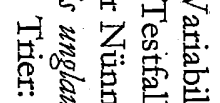

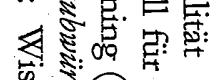

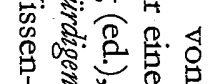

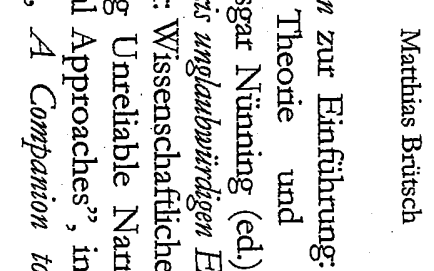

के 包若

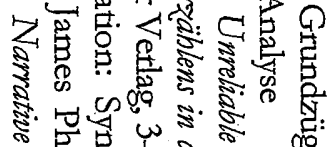

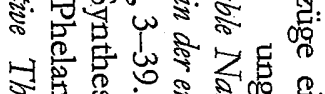

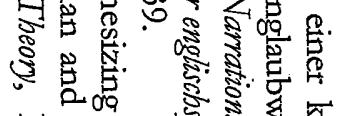
尔西

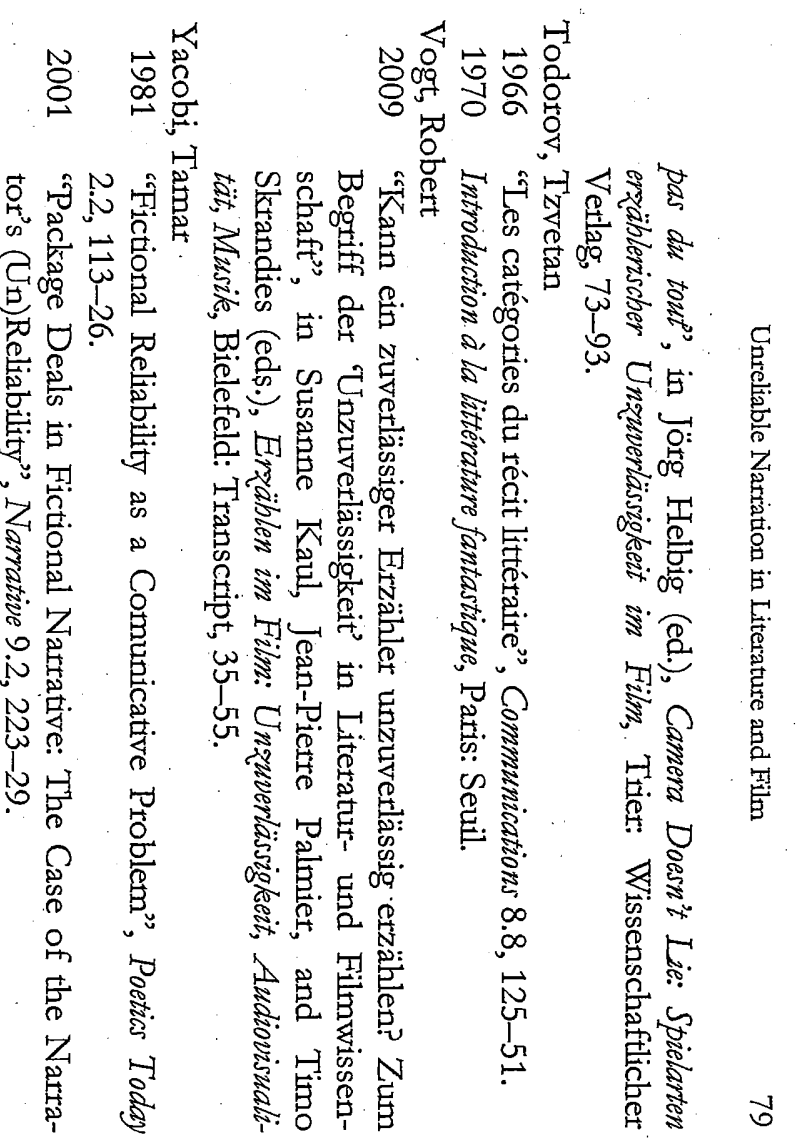

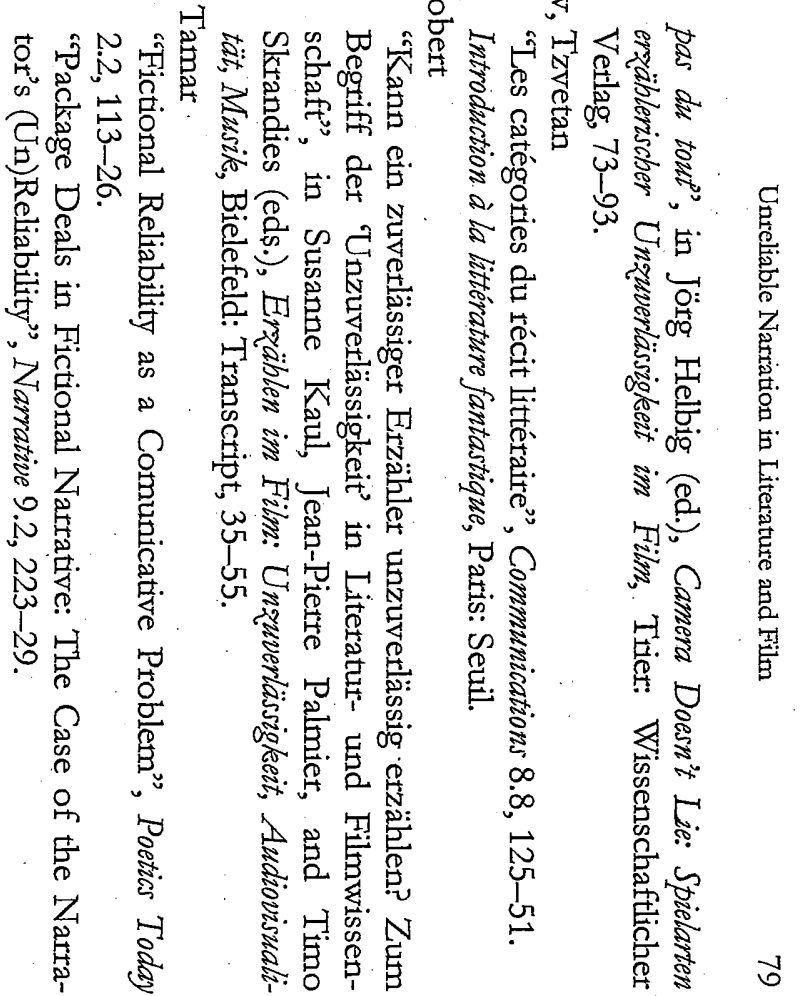

